\title{
Comparative solution equilibrium studies on pentamethylcyclopentadienyl rhodium complexes of 2,2'-bipyridine and ethylenediamine and their interaction with human serum albumin
}

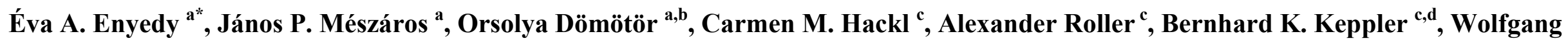 \\ Kandioller $^{c, d}$
}

${ }^{a}$ Department of Inorganic and Analytical Chemistry, University of Szeged, Dóm tér 7, H-6720 Szeged, Hungary

${ }^{\mathrm{b}}$ MTA-SZTE Bioinorganic Chemistry Research Group, University of Szeged, Dóm tér 7, H-6720 Szeged, Hungary

${ }^{\mathrm{c}}$ Institute of Inorganic Chemistry, Faculty of Chemistry, University of Vienna, Waehringer Str. 42, A-1090 Vienna, Austria

${ }^{\mathrm{d}}$ University of Vienna, Research Platform Translational Cancer Therapy Research, Waehringer Str. 42, A-1090 Vienna, Austria

Keywords: Stability Constants; X-ray Crystal Structure; Half-sandwich complexes, Rhodium, Albumin, Deferiprone.

* Corresponding author: Fax: +36 62420505

E-mail address: enyedy@chem.u-szeged.hu (E. A. Enyedy)

\section{ABSTRACT}

Complex formation equilibrium processes of the $(\mathrm{N}, \mathrm{N})$ donor containing 2,2'-bipyridine (bpy) and ethylenediamine (en) with ( $\eta^{5}$ pentamethylcyclopentadienyl)rhodium(III) were investigated in aqueous solution via $\mathrm{pH}$-potentiometry, ${ }^{1} \mathrm{H}$ NMR spectroscopy, and UV-Vis spectrophotometry in the absence and presence of chloride ions. The structure of $\left[\mathrm{RhCp}^{*}(\mathrm{en}) \mathrm{Cl}\right] \mathrm{ClO}_{4}\left(\mathrm{Cp}^{*}\right.$, pentamethylcyclopentadienyl) was also studied by single-crystal X-ray diffraction. $\mathrm{p} K_{\mathrm{a}}$ values of 8.56 and 9.58 were determined for $\left[\mathrm{RhCp} *(\mathrm{bpy})\left(\mathrm{H}_{2} \mathrm{O}\right)\right]^{2+}$ and $\left[\mathrm{RhCp} *(\mathrm{en})\left(\mathrm{H}_{2} \mathrm{O}\right)\right]^{2+}$, 
respectively resulting in the formation of negligible amount of mixed hydroxido complexes at $\mathrm{pH}$ 7.4. Stability and the $\mathrm{H}_{2} \mathrm{O} / \mathrm{Cl}^{-}$co-ligand exchange constants of bpy and en complexes considerably exceed those of the bidentate O-donor deferiprone. The strong affinity of the bpy and en complexes to chloride ions most probably contributes to their low antiproliferative effect. Interactions between human serum albumin (HSA) and $\left[\mathrm{RhCp} *\left(\mathrm{H}_{2} \mathrm{O}\right)_{3}\right]^{2+}$, its complexes formed with deferiprone, bpy and en were also monitored by ${ }^{1} \mathrm{H}$ NMR spectroscopy, ultrafiltration/UV-Vis and spectrofluorometry. Numerous binding sites $(\geq 8)$ are available for $\left[\mathrm{RhCp} *\left(\mathrm{H}_{2} \mathrm{O}\right)_{3}\right]^{2+}$; and the interaction takes place most probably via covalent bonds through the imidazole nitrogen of His. According to the various fluorescence studies $\left[\mathrm{RhCp}^{*}\left(\mathrm{H}_{2} \mathrm{O}\right)_{3}\right]^{2+}$ binds on sites I and II, and coordination of surface side chain donor atoms of the protein is also feasible. The binding of the bpy and en complex is weaker and slower compared to that of $\left[\mathrm{RhCp}^{*}\left(\mathrm{H}_{2} \mathrm{O}\right)_{3}\right]^{2+}$, and formation of ternary HSA-RhCp*-ligand adducts was proved. In the case of the deferiprone complex, the $\mathrm{RhCp} *$ fragment is cleaved off when HSA is loaded with low equivalents of the compound. 


\section{Introduction}

Organometallic compounds possess a great structural variety and have been used to a large extent in homogenous catalysis and the interest in their potential application as anticancer agents is currently increasing. Organoruthenium complexes have been identified as promising alternatives to anticancer Pt compounds since they show less severe side effects and are less toxic in general [1-3]. Ru(III) containing compounds, namely imidazolium trans-[tetrachlorido(DMSO)(imidazole)ruthenate(III)] (NAMI-A) [4], indazolium trans-[tetrachloridobis(1Hindazole)ruthenate(III)] (KP1019) [5] and its sodium salt (NKP1339/IT-139) [6] are under clinical evaluations with promising results. It has been recently reported that the catalytic activity of the $\left[\mathrm{Ru}(\mathrm{II})\left(\eta^{6}-p\right.\right.$-cymene)] complexes of sulfonamido ethyleneamine ligands can be transferred in cancer cells, which has influence on the extent of intracellular conversion of NAD ${ }^{+}$to NADH. This exciting finding offers a novel drug design concept [7]. In all, these results strongly motivate the development of novel metallodrugs with antitumor activity.

$\mathrm{Rh}(\mathrm{III})$ is isoelectronic with $\mathrm{Ru}(\mathrm{II})$, and the kinetic intertness of the $\left[\mathrm{Rh}\left(\mathrm{H}_{2} \mathrm{O}\right)_{6}\right]^{3+}$ complex can be overcome by coordination of neutral arene or especially by anionic pentamethylcyclopentadienyl ligands [8,9]. Among the half-sandwich organorhodium compounds foremost $\left(\eta^{5}\right.$ pentamethylcyclopentadienyl)rhodium(III) ( $\mathrm{RhCp}^{*}$ ) complexes of 1,3,5-triaza-7-phosphatricyclo-[3.3.1.1]decane (PTA) were tested for in vitro antiproliferative activity, but their efficacy was negligible [10]. Recently, we reported RhCp* complexes of (O,O) donor containing 3-hydroxy-4pyrone ligands [11] and 1,2-dimethyl-3-hydroxy-pyridin-4(1H)-one (deferiprone, dhp) [12], which showed cytotoxicity with $\mathrm{IC}_{50}$ values of 50 $300 \mu \mathrm{M}$, respectively in cancer cell lines. Whereas RhCp* complexes formed with 2-picolinic acid (pic) [12] and 3-hydroxy(thio)pyrones derivatized by morpholine, piperidine or N-methylpyrazine moieties [13] exhibited only poor or no bioactivity. Promising in vitro antiproliferative activities have been reported for the RhCp* complexes of (N,N) polypyridyl (pp) ligands by Sheldrick et al. [14-17] possessing $\mathrm{IC}_{50}$ values in the low micromolar range. However, the $\mathrm{RhCp} *$ complexes of the simplest bidentate alkylamino and aromatic $\mathrm{N}-$ donor ligands, namely ethylenediamine (en) and 2,2'-bipyridine (bpy) did not show significant cytotoxicity ( $\mathrm{IC}_{50}>100 \mu \mathrm{M}$ measured in MCF-7 and HT-29 
cells) [17]. On the contrary the antiproliferative activity of $\left[\mathrm{Ru}(\mathrm{II})\left(\eta^{6}-p\right.\right.$-cymene $\left.)(\mathrm{en}) \mathrm{Cl}\right] \mathrm{PF}_{6}$ and $\left[\mathrm{Ru}(\mathrm{II})\left(\eta^{6}-\right.\right.$ biphenyl $\left.)(\mathrm{en}) \mathrm{Cl}\right] \mathrm{PF}_{6}$ complexes developed in the laboratory of Sadler is comparable to carboplatin ( $\mathrm{IC}_{50} 6-9 \mu \mathrm{M}$ measured in $\mathrm{A} 2780$ cells) [18].

In addition, $\left[\mathrm{RhCp} *(\mathrm{bpy})\left(\mathrm{H}_{2} \mathrm{O}\right)\right]^{2+}($ Chart 1$)$ is known as one of the most successful non-enzymatic catalysts and used to regenerate nicotinamide cofactors (e.g. $\mathrm{NAD}(\mathrm{P}) \mathrm{H})$ associated to dehydrogenase enzymes in aqueous solution [19-22]. It was pointed out that the electrocatalytic efficiency of the complex is strongly influenced by the experimental conditions such as $\mathrm{pH}$, the presence of chloride ions, peptides or amino acids $[19,20]$. Interaction of $\left[\mathrm{RhCp} *(\mathrm{bpy})\left(\mathrm{H}_{2} \mathrm{O}\right)\right]^{2+}$ with bovine serum albumin and His, Cys, Trp and Met amino acids decreased the activity in formate-driven reduction of $\mathrm{NAD}^{+}$. Notably the activity was also diminished in the presence of halide ions [20]. Although [RhCp*(bpy) $\left.\left(\mathrm{H}_{2} \mathrm{O}\right)\right]^{2+}$ has been extensively studied in solution [23,24], and its solid phase structure was also published [25], no solution stability data are available in the literature, only the $\mathrm{p} K_{\mathrm{a}}$ value for the deprotonation of the complex was reported [8,20].

Therefore, one of the aims of the present study was to characterize the solution speciation of the RhCp* complex of bpy in aqueous solution involving the influence of the presence of chloride ions. On the other hand, the organometallic complexes are considered as prodrugs and can undergo ligand exchange under physiological conditions, thus the knowledge of the stability and lability of the metal-leaving group, metal-chelate bonds is vital for understanding and then controlling their bioactivity. Detailed solution equilibrium studies on RhCp* complexes are rare in the literature [26-29], especially which provide stability constants. In our previous works complex formation equilibrium processes of $\mathrm{RhCp} *$ complexes were investigated in the case of $(\mathrm{O}, \mathrm{O})$ donor hydroxypyr(idin)one ligands and the $(\mathrm{O}, \mathrm{N})$ donor pic [11,12]. In the work reported here, we determined the stability constants of the $\mathrm{RhCp}$ * complexes of bpy and en (Chart 1) formed in aqueous solution to provide comparable thermodynamic data and specify the solution speciation under physiologically more relevant conditions. Bpy serves as simplified model for pp ligands as well. Additionally, interaction between the most important non-specific blood transfer protein, human serum albumin (HSA) and the en, bpy and the biologically more active deferiprone complexes was investigated by ${ }^{1} \mathrm{H}$ NMR, ultrafiltration, fluorometry involving well-established site markers for sites I and II and amino acid side chain models.

\section{Chart 1}




\section{Experimental}

\subsection{Chemicals}

All solvents were of analytical grade and used without further purification. En, bpy, dhp, $\mathrm{KCl}, \mathrm{KNO}_{3}, \mathrm{NaCl} \mathrm{AgNO}_{3}, \mathrm{HCl}, \mathrm{HNO}$, $\mathrm{KOH}, 4,4-$ dimethyl-4-silapentane-1-sulfonic acid (DSS), 1-methylimidazole (N-MeIm), N-acetyl-L-cysteine methyl ester (N-ACMe), N-acetyl-Lmethionine (N-AM), dansylglycine (DG), warfarin (WF), HSA (as lyophilized powder with fatty acids, $\mathrm{A}_{1653}$ ), $\mathrm{KH}_{2} \mathrm{PO}_{4}, \mathrm{NaH}_{2} \mathrm{PO}_{4}, \mathrm{Na}_{2} \mathrm{HPO}_{4}$ were purchased from Sigma-Aldrich in puriss quality. Doubly distilled Milli-Q water was used for preparation of samples. Dimeric rhodium precursor $\quad\left[\text { rhodium }(\mathrm{III})\left(\eta^{5}-1,2,3,4,5 \text {-pentamethylcyclopentadienyl }\right)(\mu-\mathrm{Cl}) \mathrm{Cl}\right]_{2} \quad\left([\mathrm{RhCp} *(\mu-\mathrm{Cl}) \mathrm{Cl}]_{2}\right)$ and chlorido[ethylenediamine- $\left.\kappa^{2} \mathrm{~N}\right]\left(\eta^{5}-\right.$ pentamethylcyclopentadienyl)rhodium(III) perchlorate $\left([\mathrm{RhCp} *(\mathrm{en}) \mathrm{Cl}] \mathrm{ClO}_{4}\right)$ were prepared according to literature procedures $[17,30]$, although $\mathrm{AgClO}_{4}$ was used instead of $\mathrm{AgCF}_{3} \mathrm{SO}_{3}$ in the latter case. Elemental analyses were carried out with a PerkinElmer $2400 \mathrm{CHN}$ Elemental Analyzer by the Microanalytical Laboratory of the University of Vienna. The exact concentration of the ligand stock solutions together with the proton dissociation constants were determined by $\mathrm{pH}$-potentiometric titrations with the help of the computer program HYPERQUAD [31]. $\mathrm{RhCp}^{*}$ stock solutions were obtained by dissolving a known amount of $[\mathrm{RhCp} *(\mu-\mathrm{Cl}) \mathrm{Cl}]_{2}$ in water, while the stock solution of $\left[\mathrm{RhCp} *\left(\mathrm{H}_{2} \mathrm{O}\right)_{3}\right]\left(\mathrm{NO}_{3}\right)_{2}$ was obtained from an aqueous solution of $[\mathrm{RhCp} *(\mu-\mathrm{Cl}) \mathrm{Cl}]_{2}$ after removal of chloride ions using equivalent amounts of $\mathrm{AgNO}_{3}$. The exact concentrations of the $\mathrm{RhCp} *$ stock solutions (with or without chloride) were checked by $\mathrm{pH}$-potentiometric titrations employing stability constants for $\left[\left(\mathrm{RhCp}^{*}\right)_{2}(\text { hydroxido })_{\mathrm{i}}\right](\mathrm{i}=2$ or 3$)$ complexes [11].

HSA solution was freshly prepared before the experiments and its concentration was estimated from its UV absorption: $\varepsilon_{280} \mathrm{~nm}(\mathrm{HSA})=$ $36850 \mathrm{M}^{-1} \mathrm{~cm}^{-1}$ [32]. Solutions of WF and DG were prepared prior to the analyses with one equivalent of $\mathrm{NaOH}$ and their concentrations were calculated on the basis of their UV-Vis spectra: $\varepsilon_{308} \mathrm{~nm}(\mathrm{WF})=14475 \mathrm{M}^{-1} \mathrm{~cm}^{-1}, \varepsilon_{327 \mathrm{~nm}}(\mathrm{DG})=5068 \mathrm{M}^{-1} \mathrm{~cm}^{-1}$. Stock solutions of N-MeIm, NACMe and N-AM were prepared on a weight-in-volume basis in a modified phosphate buffered saline (PBS') at pH 7.40. PBS' contains 12 mM 
$\mathrm{Na}_{2} \mathrm{HPO}_{4}, 3 \mathrm{mM} \mathrm{KH} \mathrm{PO}_{4}, 1.5 \mathrm{mM} \mathrm{KCl}$ and $100.5 \mathrm{mM} \mathrm{NaCl}$; and the concentration of the $\mathrm{K}^{+}, \mathrm{Na}^{+}$and $\mathrm{Cl}^{-}$ions corresponds to that of the human blood serum.

\section{2. pH-Potentiometric measurements}

The $\mathrm{pH}$-potentiometric measurements for determination of the proton dissociation constants of the ligands and the overall stability constants of the $\mathrm{RhCp} *$ complexes were carried out at $25.0 \pm 0.1{ }^{\circ} \mathrm{C}$ in water and at an ionic strength of $0.20 \mathrm{M} \mathrm{KCl}$ or $\mathrm{KNO}_{3}$ used for keeping the activity coefficients constant. The titrations were performed with carbonate-free $\mathrm{KOH}$ solution $(0.20 \mathrm{M})$. The exact concentrations of $\mathrm{HCl} \mathrm{HNO}_{3}$ and $\mathrm{KOH}$ solutions were determined by $\mathrm{pH}$-potentiometric titrations. An Orion 710A pH-meter equipped with a Metrohm combined electrode (type 6.0234.100) and a Metrohm 665 Dosimat burette were used for the pH-potentiometric measurements. The electrode system was calibrated to the $\mathrm{pH}=-\log \left[\mathrm{H}^{+}\right]$scale by means of blank titrations (strong acid $v$ s. strong base: $\mathrm{HCl} / \mathrm{HNO}_{3} v s . \mathrm{KOH}$ ), as suggested by Irving et al. [33]. The average water ionization constant, $\mathrm{p} K_{\mathrm{w}}$, was determined as $13.76 \pm 0.01$ at $25.0{ }^{\circ} \mathrm{C}, I=0.20 \mathrm{M}\left(\mathrm{KCl}, \mathrm{KNO}_{3}\right)$, which corresponds well to the literature [34]. The reproducibility of the titration points included in the calculations was within $0.005 \mathrm{pH}$ units. The pH-potentiometric titrations were performed in the $\mathrm{pH}$ range $2.0-11.5$. The initial volume of the samples was $10.0 \mathrm{~mL}$. The ligand concentration was $1.0-2.0 \mathrm{mM}$ and metal ion-to-ligand ratios of 1:1, 1:1.5 and 1:2 were used. The accepted fitting of the titration curves was always less than $10 \mu \mathrm{L}$. Samples were degassed by bubbling purified argon through them for $c a .10 \mathrm{~min}$ prior to the measurements and it was also passed over the solutions during the titrations.

The computer program PSEQUAD [35] was utilized to establish the stoichiometry of the complexes and to calculate the overall stability constants. $\beta\left(\mathrm{M}_{p} \mathrm{~L}_{q} \mathrm{H}_{r}\right)$ is defined for the general equilibrium:

$$
p \mathrm{M}+q \mathrm{~L}+r \mathrm{H} \rightleftharpoons \mathrm{M}_{p} \mathrm{~L}_{q} \mathrm{H}_{r} \text { as } \beta\left(\mathrm{M}_{p} \mathrm{~L}_{q} \mathrm{H}_{r}\right)=\left[\mathrm{M}_{p} \mathrm{~L}_{q} \mathrm{H}_{r}\right] /[\mathrm{M}]^{p}[\mathrm{~L}]^{q}[\mathrm{H}]^{r}
$$

where $\mathrm{M}$ denotes the metal moiety $\mathrm{RhCp}^{*}$ and $\mathrm{L}$ the completely deprotonated ligand. $\log \beta$ values of the various $\left[\left(\mathrm{RhCp}^{*}\right)_{2}(\mathrm{hydroxido})_{\mathrm{i}}\right](\mathrm{i}=2$ or 3) complexes were calculated based on the $\mathrm{pH}$-potentiometric titration data in the absence and presence of chloride ions and were found to be in a good agreement with our previously published data [11]. 


\subsection{UV-Vis spectrophotometric and fluorometric measurements}

A Hewlett Packard 8452A diode array spectrophotometer was used to record the UV-Vis spectra in the interval 200-800 nm. The path length $(l)$ was 1 or $0.5 \mathrm{~cm}$. A tandem cuvette (Hellma Tandem Cell, 238-QS, $l=1 \mathrm{~cm}$ ) was used to study the rate of complex formation of RhCp* with en and bpy, and the reactants were separated until the reaction was triggered. UV-Vis spectra were recorded before and immediately after the mixing and changes were followed till no further absorbance change was observed. One of the isolated pockets contained the ligand and its concentration was $100 \mu \mathrm{M}$ (bpy) or $200 \mu \mathrm{M}$ (en); and the other contained the equivalent amount of RhCp*. The pH values of the samples in both pockets were identical and adjusted to 1.9 or 3.8 by HCl, 7.4 by $20 \mathrm{mM}$ phosphate buffer, and 11.0 by KOH solutions. Constant ionic strength of $0.2 \mathrm{M}\left(\mathrm{KNO}_{3}\right.$ or $\left.\mathrm{KCl}\right)$ was applied. Prior to the measurements the effect of various buffers (phosphate, 4-(2-hydroxyethyl)-1piperazineethanesulfonic acid (HEPES), tris(hydroxymethyl)methylamine (Tris) and 3-(N-morpholino)propanesulfonic acid (MOPS)) on the UV-Vis spectra of the RhCp* - dhp (1:1) system was tested at $\mathrm{pH} 7.4$, and phosphate caused minimum alterations compared to the others. The spectrophotometric titrations were performed with samples containing only bpy $(0.1 \mathrm{mM}), \mathrm{RhCp} *(0.1 \mathrm{mM})$ or a 1:1 molar ratio of RhCp* and ligand $\left(0.1 \mathrm{mM}\right.$ bpy or $0.2 \mathrm{mM}$ en) over the $\mathrm{pH}$ range $2.0-11.5$ at an ionic strength of $0.20 \mathrm{M}\left(\mathrm{KCl}^{\circ} \mathrm{KNO}_{3}\right)$ and at $25.0 \pm 0.1{ }^{\circ} \mathrm{C}$. Measurements on the RhCp* complexes of bpy were also carried out in the absence and presence of chloride ions by preparing individual samples, in which the $0.20 \mathrm{M} \mathrm{KCl}$ or $\mathrm{KNO}_{3}$ was partially or completely replaced by $\mathrm{HCl}$ or $\mathrm{HNO}_{3}$ and pH values, varying in the range of approximately $0.7-2.0$, were calculated from the strong acid content. The overall stability constant of the complex [RhCp*(bpy)(Z)] was determined spectrophotometrically from competition titrations of the [RhCp*(en)Z] complex by bpy at pH 7.4 (20 mM phosphate buffer) and at an ionic strength of $0.20 \mathrm{M}(\mathrm{KCl})$. Samples contained $100 \mu \mathrm{M} \mathrm{RhCp} *$ and $100 \mu \mathrm{M}$ en, and the concentration of bpy was varied between $0-170$ $\mu \mathrm{M}$. Absorbance data recorded after $24 \mathrm{~h}$ incubation time in the wavelength interval from 240 to $500 \mathrm{~nm}$ were used for the calculations. UV-Vis spectra were also recorded to investigate the $\mathrm{H}_{2} \mathrm{O} / \mathrm{Cl}^{-}$exchange processes in the $\left[\mathrm{RhCp} *(\mathrm{~L})\left(\mathrm{H}_{2} \mathrm{O}\right)\right]^{2+}$ complexes at $\mathrm{pH} 7.4(20 \mathrm{mM}$ phosphate buffer) in dependence of the $\mathrm{Cl}^{-}$concentration (0-200 mM). Stability constants were calculated with the computer program PSEQUAD [35]. 
Fluorescence spectra were recorded on a Hitachi-F4500 fluorometer in $1 \mathrm{~cm}$ quartz cell at $25.0 \pm 0.1{ }^{\circ} \mathrm{C}$. All solutions were prepared in PBS' (pH 7.4) and were incubated for 1 or $24 \mathrm{~h}$. Samples contained $1 \mu \mathrm{M}$ HSA and various HSA-to-ligand or RhCp* or [RhCp*(L)Z] ratios (from 1:0 to 1:10) were used. In the site marker displacement experiments the HSA-to-site marker (WF or DG) ratio was 1:1 and the concentration of the compounds was varied. The excitation wavelengths were 295, 310 or $335 \mathrm{~nm}$ depending on the type of the experiment and the emission was read in the range of $310-650 \mathrm{~nm}$. The quenching $\left(K_{\mathrm{Q}}\right.$ ') or displacement constants $\left(K_{\mathrm{WF}}\right.$ ' and $\left.K_{\mathrm{DG}}{ }^{\prime}\right)$ were calculated with the computer program PSEQUAD [35] based on the equilibrium processes and mass-balance equations for the components detailed in the Supplementary data using the same approach applied in our previous works [36,37].

\section{4. ${ }^{1} \mathrm{H}$ and ${ }^{13} \mathrm{C}$ NMR measurements}

${ }^{1} \mathrm{H}$ NMR studies were carried out on a Bruker Ultrashield 500 Plus instrument. All the ${ }^{1} \mathrm{H}$ NMR spectra were recorded with the WATERGATE water suppression pulse scheme using DSS internal standard. Ligands bpy and en were dissolved in a $10 \%(\mathrm{v} / \mathrm{v}) \mathrm{D}_{2} \mathrm{O} / \mathrm{H}_{2} \mathrm{O}$ mixture to yield a concentration of 1 or $2 \mathrm{mM}$ and were titrated at $25{ }^{\circ} \mathrm{C}$, at $I=0.20 \mathrm{M}\left(\mathrm{KCl}\right.$ or $\left.\mathrm{KNO}_{3}\right)$ in absence or presence of RhCp* at 1:1 metal-to-ligand ratio. Stability constants for the complexes were calculated by the computer program PSEQUAD [35]. To study the interaction with HSA and the binding site model compounds (N-MeIm, N-ACMe, N-AM) ${ }^{1} \mathrm{H}$ NMR spectra were recorded for samples containing RhCp* (1 mM or $0.75 \mathrm{mM}$ ), the ligands (en, bpy, dhp) at 1:1 metal-to-ligand ratio with or without half-equivalent of HSA or one equivalent of the binding site model, respectively. Samples were prepared in PBS' buffer and incubated for $24 \mathrm{~h}$ at $25^{\circ} \mathrm{C}$.

${ }^{1} \mathrm{H}$ and ${ }^{13} \mathrm{C}$ NMR spectra of complex $\left[\mathrm{RhCp}^{*}(\mathrm{en}) \mathrm{Cl}\right] \mathrm{ClO}_{4}$ dissolved in $\mathrm{CDCl}_{3}$ were recorded at $25{ }^{\circ} \mathrm{C}$ using a Bruker FT-NMR spectrometer Avance III ${ }^{\mathrm{TM}}$.

\subsection{Membrane ultrafiltration/UV-Vis measurements}

Samples were separated by ultrafiltration through $10 \mathrm{kDa}$ membrane filters (Microcon YM-10 centrifugal filter unit, Millipore) in low (LMM) and high molecular mass (HMM) fractions with the help of a temperature controlled centrifuge (Sanyo, 10000/s, $10 \mathrm{~min})$. Samples (0.50 mL) 
contained $50 \mu \mathrm{M}$ HSA and RhCp* or its en, bpy and dhp complexes $\left(50,150,450 \mu \mathrm{M}\right.$ ) in PBS' buffer (pH 7.4) at $25.0 \pm 0.1{ }^{\circ} \mathrm{C}$ and were incubated for $1 \mathrm{~h}$ or $24 \mathrm{~h}$. The LMM fraction containing the non-bound metal complex was separated from the protein and its adducts in the HMM fraction. The concentration of the non-bound compounds in the LMM fractions was determined by UV-Vis spectrophotometry by comparing the recorded spectra to those of reference samples without the protein. When the complex partly decomposed due to the protein binding, free ligand was also detected in the LMM fraction. In this case the recorded spectrum was deconvoluted with the aid of the molar absorbance spectra of the ligand and metal complex by Excel Solver (Microsoft Office 2007).

\subsection{Synthesis and crystallographic structure determination of complex [RhCp*(en) Cl] $\mathrm{ClO}_{4} \cdot 2 \mathrm{H}_{2} \mathrm{O}$ (1)}

Two equivalents of silver perchlorate $(41 \mathrm{mg}, 0.2 \mathrm{mmol}, 2 \mathrm{eq})$ were added in one portion to a solution of $[\mathrm{RhCp} *(\mu-\mathrm{Cl}) \mathrm{Cl}]_{2}(62 \mathrm{mg}, 0.1$ $\mathrm{mmol}, 1 \mathrm{eq}) \mathrm{in}$ acetone $(10 \mathrm{~mL})$ and stirred at ambient temperature protected from light irradiation for $0.5 \mathrm{~h}$. The formed $\mathrm{AgCl}$ precipitate was filtered off and the solvent was removed under reduced pressure resulting in $\left[\mathrm{RhCp} *(\text { acetone })_{2} \mathrm{Cl}\right] \mathrm{ClO}_{4}$ which was stirred with en $(12 \mathrm{mg}, 0.2$ mmol, 2 eq) dissolved in a mixture of $\mathrm{CH}_{3} \mathrm{OH}$ and $\mathrm{CH}_{2} \mathrm{Cl}_{2}(1: 1,15 \mathrm{~mL})$ at room temperature for $2 \mathrm{~h}$. The color of the solution changed from dark orange to yellow. Removal of the solvent mixture under reduced pressure afforded a yellow solid which was dissolved in $2 \mathrm{~mL}$ water. Yellow needle-like crystals appeared after $12 \mathrm{~h}$ which were suitable for X-ray data collection. ${ }^{1} \mathrm{H} \mathrm{NMR}\left(500.10 \mathrm{MHz}, \mathrm{CDCl}_{3}\right): \delta=1.69\left(\mathrm{~s}, 15 \mathrm{H}, \mathrm{CH}_{3, \mathrm{Cp}} *\right.$, 2.31-2.42 (m, 2H, $\left.\mathrm{CH}_{2, \text { en }}\right), 2.45-2.56\left(\mathrm{~m}, 2 \mathrm{H}, \mathrm{CH}_{2, \mathrm{en}}\right), 4.21-4.32\left(\mathrm{~m}, 2 \mathrm{H}, \mathrm{NH} H_{2, \mathrm{en}}\right), 5.03-5.15\left(\mathrm{~m}, 2 \mathrm{H}, \mathrm{NH}_{2, \mathrm{en}}\right) ;{ }^{13} \mathrm{C} \mathrm{NMR}\left(125.75 \mathrm{MHz}, \mathrm{CDCl}_{3}\right): \delta$ $=8.5\left(\mathrm{CH}_{3, \mathrm{Cp}^{*}}\right), 44.2\left(\mathrm{CH}_{2, \text { en }}\right), 93.6\left(\mathrm{C}_{\mathrm{Cp}} *\right)$. Elemental analysis $(\%)$ for $\mathrm{C}_{12} \mathrm{H}_{23} \mathrm{Cl}_{2} \mathrm{~N}_{2} \mathrm{O}_{4} \mathrm{Rh} \cdot 2 \mathrm{H}_{2} \mathrm{O}$ calc. C: 30.72; $\mathrm{H}: 5.80 ; \mathrm{N}: 5.97$; found: $\mathrm{C}: 30.49$; H: $5.91 ; \mathrm{N}: 5.88$.

Single crystals of $\left[\mathrm{RhCp}^{*}(\mathrm{en}) \mathrm{Cl}\right] \mathrm{ClO}_{4} \cdot 2 \mathrm{H}_{2} \mathrm{O}(\mathbf{1})$ were analyzed on a Bruker D8 Venture diffractometer at $100 \mathrm{~K}$. The single crystal was positioned at $34 \mathrm{~mm}$ from the detector and 1698 frames for $4 \mathrm{~s}$ exposure time over $0.4^{\circ}$ scan width were measured. The data were processed using the SAINT software package [38]. The structures were solved by direct methods and refined by full-matrix least-squares techniques. Nonhydrogen atoms were refined with anisotropic displacement parameters. Secondary $\mathrm{CH}_{2}$ and $\mathrm{NH}_{2}$ hydrogen atoms were inserted with a riding model. Idealized methyl hydrogen atoms were refined as rotating groups. The following computer programs were used: structure solution, 
SHELXS-97 [39]; refinement, SHELXL-2013 [39]; OLEX2 [40]; SHELXLE [41]; molecular diagrams, ORTEP-3 [42]; scattering factors [43]. The crystallographic data files for complex 1 have been deposited with the Cambridge Crystallographic Database as CCDC 1062657. Crystal data and structure refinement details for complex $\mathbf{1}$ are given in Table S1.

\section{Results and discussion}

\subsection{Acid-base properties of the studied ligands and the $\left[\mathrm{RhCp} *\left(\mathrm{H}_{2} \mathrm{O}\right)_{3}\right]^{2+}$ cation}

Proton dissociation constants of en and bpy (Chart 1) determined by pH-potentiometry and ${ }^{1} \mathrm{H}$ NMR titrations (Table 1, Fig. S1) are in reasonably good agreement with data reported in the literature under identical conditions as used in this study $\left(I=0.2 \mathrm{M} \mathrm{KNO}{ }_{3}\right.$ or $\left.0.2 \mathrm{M} \mathrm{KCl}\right)$ [44-47]. Hydrolytic behavior of the $\left[\mathrm{RhCp} *\left(\mathrm{H}_{2} \mathrm{O}\right)_{3}\right]^{2+}$ organometallic cation was already studied [11,26], and the structure of the major hydrolysis product, $\left[\left(\mathrm{RhCp}^{*}\right)_{2}(\mu-\mathrm{OH})_{3}\right]^{+}$, was characterized by single-crystal X-ray analysis [29]. Overall stability constants for the $\mu$-hydroxido-bridged dinuclear species $\left(\left[\left(\mathrm{RhCp}^{*}\right)_{2}(\mu-\mathrm{OH})_{3}\right]^{+}\right.$and $\left.\left[\left(\mathrm{RhCp}^{*}\right)_{2}(\mu-\mathrm{OH})_{2}\right]\right)$ were reported at various ionic strengths in our previous work [11], and these data were utilized for our calculations.

\section{Table 1}

\subsection{Complex formation equilibria of $\left[\mathrm{RhCp} *\left(\mathrm{H}_{2} \mathrm{O}\right)_{3}\right]^{2+}$ with en and bpy}

Complex formation equilibrium processes of $\left[\mathrm{RhCp} *\left(\mathrm{H}_{2} \mathrm{O}\right)_{3}\right]^{2+}$ with en and bpy were studied in aqueous solution by the combined use of $\mathrm{pH}-$ potentiometric, ${ }^{1} \mathrm{H}$ NMR and UV-Vis titrations in the absence and presence of chloride ions. The stoichiometries and overall stability constants of the complexes furnishing the best fits to the experimental data are listed in Table 1. Complex formation and co-ligand exchange equilibrium processes are represented in Chart 2.

\section{Chart 2}


Since chloride ion possibly coordinates by replacing partly the aqua ligands, the stability constants determined in the chloride-containing medium are regarded as conditional stability constants and are valid only under the given conditions. It is known that the rate of the ligand substitution reactions in the half-sandwich cation $\left[\mathrm{RhCp} *\left(\mathrm{H}_{2} \mathrm{O}\right)_{3}\right]^{2+}$ is strongly determined by the nature of the chelating ligands [8]. Therefore, first of all complexation between $\mathrm{RhCp}^{*}$ and the ligands (en and bpy) was followed spectrophotometrically at three different $\mathrm{pH}$ values in order to monitor the reaction rates (Fig. S2). It was found that the equilibrium can be reached relatively fast in all cases $(<10$ min) except the en containing samples at $\mathrm{pH}$ between $\sim 2$ and $\sim 4$ where unusual long waiting time (up to 60 min) was needed.

According to the pH-potentiometric titration curves (Fig. S3) recorded at two experimental setups $\left(I=0.2 \mathrm{M} \mathrm{KCl}\right.$ or $\left.\mathrm{KNO}_{3}\right)$ complexation takes place already at the starting $\mathrm{pH}(\sim 2)$ with en, while proton displacement by the metal ion is almost complete at this $\mathrm{pH}$ in the case of bpy. Consequently, overall stability constants could be determined only for the mono-ligand complex $\left[\mathrm{RhCp}^{*}(\mathrm{en}) \mathrm{Z}\right]\left(\mathrm{Z}=\mathrm{H}_{2} \mathrm{O}\right.$ and/or $\mathrm{Cl}^{-}$; charges are omitted for simplicity). In this complex en coordinates via the neutral bidentate $(\mathrm{N}, \mathrm{N})$ donor set as the X-ray structure of complex 1 as described in Section 3.3; and the coordination sphere is completed with an aqua or chlorido ligand depending on the chloride ion content of the solution. Based on the $\mathrm{pH}$-potentiometric titrations (Fig. S3.a) $\mathrm{p} K_{\mathrm{a}}$ values of the [RhCp*(en)Z] complexes could be determined only with large uncertainties, thus $\mathrm{pH}$-dependent ${ }^{1} \mathrm{H}$ NMR spectra were recorded (Figs. 1, S4). Due to the slow ligand-exchange processes on the NMR time scale $\left(t_{1 / 2}(\mathrm{obs}) \sim 1 \mathrm{~ms}\right)$ peaks belonging to the free or bound ligand and to the bound or non-bound metal ion could be detected separately. Then the integrated peak areas of the $\mathrm{Cp}^{*}$ methyl protons were converted to molar fractions of the bound $\mathrm{RhCp}^{*}$, which were also calculated with the aid of the $\log \beta$ values of species [RhCp*(en)Z] (Fig. 1.b). Fairly good correlation between the data of both methods was observed. Additionally, in the chloride-free medium the upfield shift of the peak belonging to $\left[\mathrm{RhCp} *(\mathrm{en})\left(\mathrm{H}_{2} \mathrm{O}\right)\right]^{2+}$ was observed in the basic pH range $($ Fig. $\mathrm{S} 4 . \mathrm{a})$ strongly indicating the formation of the mixed hydroxido species, $[\mathrm{RhCp} *(\mathrm{en})(\mathrm{OH})]^{+}$(Chart 2). Thus, $K_{\mathrm{a}}$ of the aqua complex could be determined on the basis of the $\mathrm{pH}$-dependent $\delta$ values (Fig. S4.b, Table 1). Notably, in the presence of chloride ions the signals of species $\left[\mathrm{RhCp}^{*}(\mathrm{en}) \mathrm{Z}\right]$ and $\left[\mathrm{RhCp}^{*}(\mathrm{en})(\mathrm{OH})\right]^{+}$were observed more separately (Fig. 1.a); although the $\mathrm{p} K_{\mathrm{a}}$ value could be not calculated due to the nonsatisfactory peak separation and was determined by the deconvolution of the pH-dependent UV-Vis spectra (Fig. S5).

Fig. 1 
The ${ }^{1} \mathrm{H}$ NMR spectra recorded for the $\mathrm{RhCp}^{*}$ - bpy system undoubtedly reveal the predominant formation of the complex [RhCp*(bpy)Z] in the $\mathrm{pH}$ ranges $1.9-\sim 7$ and $1.9-\sim 8.5$ at ionic strengths of $0.2 \mathrm{M} \mathrm{KNO}_{3}$ and $\mathrm{KCl}$, respectively (Fig. S6). Since neither free metal ion nor ligand could be detected at the starting $\mathrm{pH}$ values at $\mathrm{mM}$ concentrations, UV-Vis spectra were recorded under more diluted conditions and at strongly acidic $\mathrm{pH}$ values. The unaltered spectra at $\mathrm{pH}$ between $0.7-8.5$ (Fig. 2) revealed that the complex [RhCp*(bpy)Z] does not decompose in this $\mathrm{pH}$ range due to its outstanding high stability. Therefore the $\log \beta$ value for this complex was determined spectrophotometrically by competition reactions with en in the presence of chloride ions at $\mathrm{pH} 7.4$ (Fig. S7). At this $\mathrm{pH}$ RhCp* forms $\left[\mathrm{RhCp}^{*}(\mathrm{~L}) \mathrm{Z}\right]$ species with both ligands predominantly. Absorption bands of the metal-bound and free bpy were significantly different in the wavelength $(\lambda)$ range 240 and $340 \mathrm{~nm}$ allowing the calculation of the stability constant of the bpy complex (Table 1).

Fig. 2

The $\mathrm{p} K_{\mathrm{a}}$ values of the $\left[\mathrm{RhCp}{ }^{*}(\mathrm{bpy}) \mathrm{Z}\right]$ complexes were determined by $\mathrm{pH}$-potentiometry, by the deconvolution of $\mathrm{pH}$-dependent UV-Vis spectra (representative spectra are shown in Fig. 2 recorded in the chloride-containing medium), and by ${ }^{1} \mathrm{H}$ NMR spectroscopy (Fig. S6). $\mathrm{p} K_{\mathrm{a}}$ values determined by the different methods are in reasonably good agreement with each other (Table 1). The constant obtained in the absence of chloride ions is comparable to previously published data ( $\mathrm{p} K_{\mathrm{a}}=8.5$ [20]; $\mathrm{p} K_{\mathrm{a}}=8.2$ [8]).

Representative concentration distribution curves were calculated with the aid of stability constants determined for the $\left[\mathrm{RhCp}^{*}\left(\mathrm{H}_{2} \mathrm{O}\right)_{3}\right]^{2+}-$ en system in both medium studied (Fig. 3). These curves and the stability data (Table 1) clearly reveal the significant effect of the chloride ions on the solution speciation. Namely, the complex formation starts at somewhat lower $\mathrm{pH}$ values in the absence of the competitor chloride ions; thus higher $\log \beta\left[\mathrm{RhCp}^{*}(\mathrm{~L}) \mathrm{Z}\right]$ values were obtained. On the other hand, chloride ions suppress the hydrolysis, as it was documented for analogous half-sandwich organometallic complexes as well $[18,48,49]$. The complete or partial displacement of the aqua ligand by chloride ions or vice versa at the third coordination site of $\mathrm{RhCp}^{*}$ (Chart 2) may have an impact on the bioactivity, since aquation of the chlorido complexes is considered as an important step in the mechanism of action as in the case of many anticancer metallodrugs [50-53]. Therefore the $\left[\mathrm{RhCp}^{*}(\mathrm{~L})\left(\mathrm{H}_{2} \mathrm{O}\right)\right]^{2+}+\mathrm{Cl}^{-} \rightleftarrows\left[\mathrm{RhCp}^{*}(\mathrm{~L})(\mathrm{Cl})\right]^{+}+\mathrm{H}_{2} \mathrm{O}(\mathrm{L}=$ en or bpy) equilibrium was also studied spectrophotometrically. The exchange process 
was found to be fast and $\log K\left(\mathrm{H}_{2} \mathrm{O} / \mathrm{Cl}^{-}\right)$constants (Table 1) were estimated with the deconvolution of UV-Vis spectra of the $\left[\mathrm{RhCp}^{*}(\mathrm{~L})\left(\mathrm{H}_{2} \mathrm{O}\right)\right]^{2+}$ complexes recorded at various chloride concentrations (see Fig. S8 for the en complex). The obtained $\log K\left(\mathrm{H}_{2} \mathrm{O} / \mathrm{Cl}^{-}\right)$constants are significantly high, thus represent a strong affinity of the en and bpy complexes towards the chloride ions.

Fig. 3

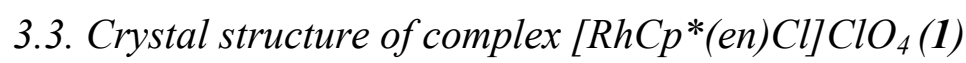

The en complex of $\mathrm{RhCp}^{*}$ as [ $\left.\mathrm{RhCp}^{*}(\mathrm{en}) \mathrm{Cl}\right] \mathrm{Cl}$ was prepared and characterized previously [54], although crystal structure was not provided. The molecular structure of complex cation $\left[\mathrm{RhCp}^{*}(\mathrm{en}) \mathrm{Cl}\right]^{+}$has been established in this work by single-crystal X-ray analysis as its perchlorate salt (Fig. 4). Crystallographic data are collected in Table S1, and selected bond lengths and angles are listed in the legend of Fig. 4. Complex 1 adopts the expected piano-stool geometry with the rhodium(III) center being coordinated by a pentamethylcyclopentadienyl ring, a chlorido ligand and the $(\mathrm{N}, \mathrm{N})$ chelating en. The metal ion to ring centroid distance of $1.7630 \AA$ is somewhat shorter than the reported value for the [RhCp*(bpy)Cl] $\mathrm{ClO}_{4}$ complex $(1.776 \AA)$, while the $\mathrm{Rh}-\mathrm{N}, \mathrm{N}^{\prime}$ (2.1452 $\AA$ and $\left.2.1234 \AA\right)$ and $\mathrm{Rh}-\mathrm{Cl}(2.4339 \AA)$ bond lengths are longer in the en complex. Distances of 2.100 and $2.385 \AA$ were obtained for the $\mathrm{Rh}-\mathrm{N}, \mathrm{N}^{\prime}$ and $\mathrm{Rh}-\mathrm{Cl}$ bonds, respectively in the [RhCp*(bpy)Cl] ${ }^{+}$cation [8] and bond lengths of 2.093 and $2.115 \AA$ were reported for the Rh-N(1) and Rh-N(2) bonds in the $\left[\mathrm{RhCp} *(b p y)\left(\mathrm{H}_{2} \mathrm{O}\right)\right]\left(\mathrm{CF}_{3} \mathrm{SO}_{3}\right)_{2}$ complex [19]. The structure of the analogous iridium(III) complex $[\mathrm{IrCp} *(\mathrm{en}) \mathrm{Cl}] \mathrm{CF}_{3} \mathrm{SO}_{3}$ has been also published representing a close structural similarity to complex 1, although slightly shorter distances between metal ion and the coordinating donor atoms $(\mathrm{N}, \mathrm{Cl})$ or the $\mathrm{Cp}^{*}$ ring centroid are reported [55].

\section{Fig. 4}

\subsection{Comparison of solution stability and bioactivity of $R h C p *$ complexes formed with en and bpy, $(O, N)$ and $(O, O)$ bidentate ligands}

The biological activity of an organorhodium compound most likely depends on numerous factors such as lipophilicity, geometry, charge, solution stability, kinetic inertness/lability. Our aim in this work was to reveal the differences in the solution behavior of RhCp* complexes formed with 
bidentate alkylamine and aromatic N-donor ligands and to compare the obtained thermodynamic stability data to those of complexes containing $(\mathrm{N}, \mathrm{O})$ and $(\mathrm{O}, \mathrm{O})$ donor sets with respect to their in vitro antiproliferative effects. In order to demonstrate the difference in the RhCp* binding ability of the chosen ligands the negative logarithm of the summed equilibrium concentrations of the non-bound metal ion in its $\left[\mathrm{RhCp}^{*}\left(\mathrm{H}_{2} \mathrm{O}\right)_{3}\right]^{2+}$ and $\mu$-hydroxido bridged dinuclear $\left(\left[\left(\mathrm{RhCp}^{*}\right)_{2}(\mathrm{OH})_{\mathrm{i}}\right], \mathrm{i}=2\right.$ or 3$)$ forms were computed under identical conditions (Fig. 5). This is a similar way as pM values are calculated for chelating agents [56], however with this approach the fraction of the hydrolyzed metal ion species, which becomes higher and higher with increasing $\mathrm{pH}$, is also taken into consideration. The higher $\mathrm{pM}$ value indicates a stronger metal ion binding ability. Pic and dhp were chosen as representatives of the $(\mathrm{O}, \mathrm{N})$ and $(\mathrm{O}, \mathrm{O})$ donor ligands $[11,12]$. The calculations reveal the following stability trend at physiological pH: bpy $>$ en $>$ pic $>$ dhp.

Fig. 5

Based on the stability constants determined it can be also concluded that the $\left[\mathrm{RhCp}^{*}(\mathrm{~L}) \mathrm{Z}\right]$ complexes of bpy and en predominate even at $1 \mu \mathrm{M}$ concentration at $\mathrm{pH} 7.4$ (Table 1 ). On the other hand, the formation of the mixed hydroxido complexes $[\mathrm{RhCp} *(\mathrm{~L})(\mathrm{OH})]^{+}$is completely suppressed in the presence of $0.2 \mathrm{M}$ chloride ions. $\mathrm{p} K_{\mathrm{a}}$ value of the en complex is found to be higher than that of the bpy under both studied conditions as it was also found for the analogous IrCp* complexes of these ligands [57].

For a deeper insight into the relationships between solution thermodynamic data such as stability (pM), chloride ion affinity (log $K$ $\left.\left(\mathrm{H}_{2} \mathrm{O} / \mathrm{Cl}^{-}\right)\right)$, acidity $\left(\mathrm{p} K_{\mathrm{a}}\right.$ of $\left.\left[\mathrm{RhCp}^{*}(\mathrm{~L}) \mathrm{Z}\right]\right)$ and antiproliferative effects $\left(\mathrm{IC}_{50}\right)$ bar charts are shown for the RhCp* complexes of en and bpy as $(\mathrm{N}, \mathrm{N})$, pic as $(\mathrm{N}, \mathrm{O})$, dhp and 3-hydroxy-2-methyl-pyran-4(1H)-one (maltol) as $(\mathrm{O}, \mathrm{O})$ donor containing ligands (Fig. 6). Analysis of a few data points cannot give an overview about the multifactorial correlation between physicochemical properties and cytotoxicity; however, some conclusions can be still drawn based on this figure. Namely, no correlation is seen between the $\mathrm{IC}_{50}$ and pM values: the cytotoxicity does not follow the solution stability order. The $\mathrm{p} K_{\mathrm{a}}$ values of these complexes are relatively high $(\geq 8.56)$ resulting in negligible amount of mixed hydroxido species at $\mathrm{pH}$ 7.4, which are usually considered to be less reactive [51]. This can be a possible explanation for the lack of correlation between $\mathrm{p} K_{\mathrm{a}}$ and $\mathrm{IC}_{50}$ values. No correlation was found for the aquated IrCp* complexes of 1,10-phenanthroline (phen), bpy and en ligands as well [57]. On the other hand, complexes of bpy, en and pic show fairly poor or no activity against various human cancer cell lines [12,17], while 
their $\log K\left(\mathrm{H}_{2} \mathrm{O} / \mathrm{Cl}^{-}\right)$values are $\sim 1$ order of magnitude higher than those of the hydroxypyr(idin)one complexes with $(\mathrm{O}, \mathrm{O})$ donor sets [11,12]. Thus, the stronger affinity of the complexes for retaining the chlorido ligand at the third coordination site may explain the diminished activity. However, no comparable $\mathrm{H}_{2} \mathrm{O} / \mathrm{Cl}^{-}$exchange constants for RhCp* complexes are published in the literature to the best of our knowledge, similar findings were found for IrCp* complexes of bpy, en and phen [57], and for some Os and Ru arene complexes as well [49,58].

Fig. 6

\subsection{Interaction of RhCp* complexes of en, bpy and dhp with human serum albumin}

Binding of an anticancer metallodrugs to HSA is of considerable interest as it has a profound effect on the biodistribution, toxicity and side effects. Moreover, HSA and HSA-bound drugs are known to accumulate in solid tumors as a consequence of the enhanced permeability and retention effect, which can be an operative way of selective tumor targeting [59]. HSA has nonspecific binding pockets and the principal regions of these sites are located in subdomains IIA and IIIA called as site I and II, respectively [60,61]. Additionally, HSA contains metal binding sites such as the N-terminal site, the reduced Cys34 residue, the multi-metal binding site, and certain side chain donor atoms are also able to coordinate to the metal centers of the complexes [60,62]. Thus, in the case of a prospective metallodrug fairly diversified binding events should be taken into consideration regarding the binding modes and rates as well.

Interaction of some $\left.\left[\mathrm{RhCp}^{*}(\mathrm{~L}) \mathrm{Cl}\right)\right]$ complexes towards $\mathrm{HSA}$ was studied by ${ }^{1} \mathrm{H}$ NMR spectroscopy, ultrafiltration/UV-Vis and spectrofluorometry in order to investigate differences or similarities in the strength and nature of binding in the case of a biologically active (dhp) and non-active (en and bpy) organorhodium compounds. Notably, the coordinated chlorido ligands in these RhCp* complexes are partly substituted by water molecules in the aqueous solution; therefore $\mathrm{Z}$ (where $\mathrm{Z}=\mathrm{H}_{2} \mathrm{O} / \mathrm{Cl}^{-}$) is used in their general formulae ([RhCp* $\left.\left.(\mathrm{L}) \mathrm{Z}\right)\right]$ ). All measurements in this work were performed at $\mathrm{pH} 7.4$ using a modified phosphate buffered saline (PBS') in which the concentration of the chloride ions corresponds to that of the human blood serum $(102 \mathrm{mM})$. Based on the $\log K\left(\mathrm{H}_{2} \mathrm{O} / \mathrm{Cl}^{-}\right)$constants (Table 1) it can be estimated that $97 \%, 93 \%$ and $38 \%$ of the bpy, en and dhp [12] complexes respectively are chlorinated at this chloride concentration. $\left[\mathrm{RhCp}^{*}\left(\mathrm{H}_{2} \mathrm{O}\right)_{3}\right]^{2+}$ without 
any chelating ligand was also involved for comparison. The aqua complex hydrolyses under the condition used, e.g. at $1 \mathrm{mM}$ concentration $11 \%$ $\left[\mathrm{RhCp} *\left(\mathrm{H}_{2} \mathrm{O}\right)_{3}\right]^{2+}, 35 \%\left[\left(\mathrm{RhCp}^{*}\right)_{2}(\mu-\mathrm{OH})_{3}\right]^{+}$and $54 \%\left[\left(\mathrm{RhCp}^{*}\right)_{2}(\mu-\mathrm{OH})_{2}\left(\mathrm{H}_{2} \mathrm{O}\right)_{2}\right]^{2+}$ are present in the solution, however the former two species are possibly partly chlorinated revealing the co-existence of various species in the solution of $\left[\mathrm{RhCp}^{*}\left(\mathrm{H}_{2} \mathrm{O}\right)_{3}\right]^{2+}$. Thus all protein binding constants determined here are regarded as conditional stability constants and valid only under the given conditions. Samples were incubated at $25^{\circ} \mathrm{C}$ since the thermodynamic stability constants for the $\mathrm{RhCp}^{*}$ complexes were determined at this temperature.

First ${ }^{1} \mathrm{H}$ NMR spectra of $[\mathrm{RhCp} *(\mathrm{~L}) \mathrm{Z}]$ complexes in the absence or in the presence of HSA were recorded (Fig. 7). The binding of $\left[\mathrm{RhCp} *\left(\mathrm{H}_{2} \mathrm{O}\right)_{3}\right]^{2+}$ and $\left[\mathrm{RhCp}^{*}(\mathrm{dhp}) \mathrm{Z}\right]$ to HSA was found to be relatively fast as the spectra recorded after 1 and $24 \mathrm{~h}$ incubation periods were identical (not shown here). Signals of the Cp* methyl protons show that the original peaks of species $\left[\mathrm{RhCp}^{*}\left(\mathrm{H}_{2} \mathrm{O}\right)_{3}\right]^{2+}$ or $[\mathrm{RhCp} *(\mathrm{dhp}) \mathrm{Z}]$ disappear upon binding to HSA and the new peaks indicate the presence of several different chemical environments involving the metal center (Fig. 7.c). On the other hand, complex [RhCp*(dhp)Z] decomposes under the condition used since the liberation of the free ligand is clearly seen in the spectrum (Fig. S9). On the contrary, the interaction between HSA and RhCp* complexes of en and bpy was found to be much slower (see the differences between 1 and $24 \mathrm{~h}$ incubation in Fig. 7.a and b). (It is noteworthy that the equilibrium might not be reached after $24 \mathrm{~h}$, but longer incubation time might have no physiological relevance.) No ligand displacement by the protein was found, and the en complex retained partly its original entity without binding (Fig. 7.a). The new Cp* methyl signals detected for the en and bpy complexes in the presence of HSA are dissimilar and display significant alterations from the peaks obtained in the case of the dhp complex or $\left[\mathrm{RhCp}^{*}\left(\mathrm{H}_{2} \mathrm{O}\right)_{3}\right]^{2+}$ as well $(\mathrm{Fig}$. $\mathrm{S} 10)$. These findings strongly suggest the formation of ternary adducts of the RhCp* complexes of en, bpy with the protein.

Fig. 7

The direct interaction towards HSA was also followed by membrane ultrafiltration. The non-bound LMM fractions after separation were analyzed by UV-Vis quantification and the spectra were compared with reference spectra and/or were deconvoluted yielding the concentration of the non-bound $\mathrm{RhCp}^{*}$ complex and/or free ligand. Then the ratio of the bound compounds and HSA was calculated and plotted against the ratio of the total concentrations of the complexes and the protein (Fig. 8.a). Analysis of these data show that the binding of $\left[\mathrm{RhCp}^{*}\left(\mathrm{H}_{2} \mathrm{O}\right)_{3}\right]^{2+}$ is practically quantitative up to the applied $\sim 9$-fold excess, so true saturation was not achieved. The amount of bound RhCp* is almost the same in 
the case of the dhp complex; however we could detect free ligand in the LMM fractions. At lower $c$ (complex) / c(HSA) ratios dhp was not bound to the protein indicating that the complex decomposes as the ${ }^{1} \mathrm{H}$ NMR spectra also showed in Fig. S9. At higher excess of the complex the ligand becomes bound, but always much less dhp is bound than organometallic ion. Since there is no direct interaction between dhp and HSA [36], its binding is possible only via the formation of a ternary complex in which the $\mathrm{RhCp} *$ - $\mathrm{dhp}$ bond is not cleaved. The binding of complexes of en and bpy to HSA was found to be slow, which is reflected in the increased fractions of the bound compounds measured after $24 \mathrm{~h}$ incubation (Fig. 8a). The bpy complex does not decompose upon binding to the protein based on the UV-Vis spectra recorded after separation, and the amount of the bound metal ion is much lower compared with the case of $\left[\mathrm{RhCp} *\left(\mathrm{H}_{2} \mathrm{O}\right)_{3}\right]^{2+}$ alone. (Since ligand en has no absorption its concentration in the LMM fraction could not be determined by UV-Vis spectrometry.) The binding of the en complex is somewhat weaker compared to the bpy complex (Fig. 8.b); however 4-5 binding sites are feasible for both complexes.

\section{Fig. 8}

The interaction of the complexes of en and bpy to HSA represents non-dissociative characteristics, while the dhp complex suffers decomposition at the lower $c$ (complex) / $c$ (HSA) ratios and the protein replaces the original ligand. The latter finding strongly suggests the coordination of the RhCp* fragment to HSA. In the complexes en and bpy the chlorido/aqua ligand at the third coordination site may be substituted by a donor atom of the protein via the formation of a ternary adduct; however complex adducts formed via non-covalent interactions at the hydrophobic cavities of HSA such as sites I and II is also possible. Therefore, the binding of $\left[\mathrm{RhCp} *\left(\mathrm{H}_{2} \mathrm{O}\right)_{3}\right]^{2+}$ and $[\mathrm{RhCp} *(\mathrm{~L}) \mathrm{Z}](\mathrm{L}=\mathrm{dhp}$, en, bpy) at these sites were monitored by fluorometry. HSA contains a single Trp (214) residue near to site I that is responsible for the majority of the intrinsic fluorescence of the protein. Upon excitation at $295 \mathrm{~nm}$ its emission can be attenuated by a binding event at or close to Trp214. Addition of $\left[\mathrm{RhCp}^{*}\left(\mathrm{H}_{2} \mathrm{O}\right)_{3}\right]^{2+}$ or $[\mathrm{RhCp} *(\mathrm{dhp}) \mathrm{Z}]$ to HSA quenches the Trp214 fluorescence emission (see data points obtained after 1 and $24 \mathrm{~h}$ in Fig. 9) indicating that the conformation of the hydrophobic binding pocket is significantly affected by the binding of RhCp*. Based on the emission intensity changes quenching constants were computed. $\log K_{\mathrm{Q}}$, values of $5.8(1)$ and $5.9(1)$ obtained for $\left[\mathrm{RhCp} *\left(\mathrm{H}_{2} \mathrm{O}\right)_{3}\right]^{2+}$ and $\left[\mathrm{RhCp}^{*}(\mathrm{dhp}) \mathrm{Z}\right]$, respectively represent quite strong and similar ability to bind on site I. This similarity also suggests the dissociative feature of 
the binding of the dhp complex at least on this site. In the case of the complexes of en and bpy no quenching was observed even at 10 -fold excess of the complex and using $24 \mathrm{~h}$ incubation period.

\section{Fig. 9}

Additionally, displacement reactions with WF and DG, which are known site marker fluorescence probes for the binding sites I and II of HSA [37,60], were carried out. Displacement of the site marker from its binding pocket is accompanied by a considerable decrease in the intensity. In our case no measurable intensity changes were observed upon addition of complexes en and bpy up to 10-fold excess indicating no

or fairly weak binding on these sites. On the contrary, $\left[\mathrm{RhCp} *\left(\mathrm{H}_{2} \mathrm{O}\right)_{3}\right]^{2+}$ and $[\mathrm{RhCp} *(\mathrm{dhp}) \mathrm{Z}]$ showed similar and significant competition with the site markers (Figs. S11, S12). The WF displacement constants $\log K_{\mathrm{WF}}$ ' of 6.1(1) and 6.2(1) obtained for $\left[\mathrm{RhCp} *\left(\mathrm{H}_{2} \mathrm{O}\right)_{3}\right]^{2+}$ and $[\mathrm{RhCp} *(\mathrm{dhp}) \mathrm{Z}]$ were somewhat higher than those calculated for the competition with $\mathrm{DG}\left(\log K_{\mathrm{DG}}{ }^{\prime}=5.8(1)\right.$ for both species.)

However, the binding into the hydrophobic pockets of HSA in the case of $\left[\mathrm{RhCp}^{*}\left(\mathrm{H}_{2} \mathrm{O}\right)_{3}\right]^{2+}$ and $[\mathrm{RhCp} *(\mathrm{dhp}) \mathrm{Z}]$ was found to be rapid, which is typical for the non-covalent interactions, the coordination of protein side chains such as His (His242 at site I) or Tyr (Tyr411, possibly His 464 at site II) [63], located nearby these sites, to the RhCp* fragment is quite probable. Additionally coordination of more accessible e.g. surface donors of the protein may be responsible for the formation of the ternary RhCp*-ligand-HSA complexes. The metal ion in the RhCp* HSA system can be also bound by other solvent-exposed residues considering the high number of binding sites. Coordination preferences for His, Met and Cys residues are suggested for $\mathrm{Ru}(\mathrm{II} / \mathrm{III})$ complexes [64,65]. Tyr residue of peptides has been recently shown to coordinate to $\mathrm{RhCp} *$ via $\eta^{6}$ bonding mode [66]. Interactions of $\left[\mathrm{Ru}(\mathrm{II})\left(\eta^{6}-p \text {-cymene)(en)Cl}\right]^{+}\right.$with HSA were investigated by W. Hu et al. and binding to surface His $(128,247,510)$, Met (298) and to the free thiol Cys34 moieties was described [64]. Therefore, studies on interactions with some selected model compounds, namely N-MeIm, N-ACMe, N-AM (Chart 3), representing the functional groups of potential protein residues (His, Cys and Met, respectively) were performed by ${ }^{1} \mathrm{H}$ NMR spectroscopy. Reference spectra were recorded for the RhCp* complexes of dhp, en, bpy, for the model compounds in the absence and in the presence of $\left[\mathrm{RhCp} *\left(\mathrm{H}_{2} \mathrm{O}\right)_{3}\right]^{2+}$ to identify the species formed in the $\mathrm{RhCp}^{*}-$ bidentate ligand - model compound $(1: 1: 1)$ ternary systems. Representative ${ }^{1} \mathrm{H}$ NMR spectra for the RhCp* - bpy - N-MeIm system are shown in Fig. 10 .

\section{Chart 3}




\section{Fig. 10}

Interaction between $\left[\mathrm{RhCp}^{*}\left(\mathrm{H}_{2} \mathrm{O}\right)_{3}\right]^{2+}$ and the model compounds at 1:1 molar ratio took place fast, equilibrium was reached within $1 \mathrm{~h}$. $100 \%, 16 \%$ and $80 \%$ of $\mathrm{RhCp}^{*}$ was found to be bound to N-MeIm, N-ACMe, N-AM, respectively (Fig. S13). Notably, in the presence of equimolar N-MeIm RhCp* is in at least three kinds of chemical environment (Fig. 10.c), while two different signals are assigned to the methyl protons of the model compound suggesting the formation of various types of binary complexes most probably as in the case of [Ru(II)( $\eta^{6}-p-$ cymene)] [67]. Surprisingly, only a low fraction of binary complexes was formed with the Cys model, N-ACMe, although strictly anaerobic conditions were used to exclude atmospheric oxidation. Interaction between the dhp complex and the amino acid models was found to be fast, while the equilibrium was reached with the $(\mathrm{N}, \mathrm{N})$ donor containing complexes much slowly, thus $24 \mathrm{~h}$ incubation period was generally used. Formation of ternary complexes could be detected undoubtedly with the aid of the reference spectra in most of the cases besides the binary species. When the original ligand was replaced by the model compound the liberation of the free ligand could be observed. Then the integrated areas of the $\mathrm{CH}_{3}\left(\mathrm{Cp}^{*}\right)$ protons belonging to the various ternary and binary complexes (Fig. S13) were calculated to obtain the distribution of $\mathrm{RhCp}^{*}$ (Table 2). The distribution in the ternary systems varies with the type of the original ligand and the model compound. N-MeIm forms the highest amount of ternary adducts and is able most efficiently to replace the original ligands. Notably, the dhp complex could not retain its original entity in the presence of N-MeIm and N-AM. Based on these findings the RhCp* affinity order is the following: N-MeIm $>>\mathrm{N}-\mathrm{AM}>$ $\mathrm{N}-\mathrm{ACMe}$, thus $\operatorname{His}(N)>>\operatorname{Met}(S)>\operatorname{Cys}(S H)$.

\section{Table 2}

\section{Conclusions}

The rational design of metallodrugs requires detailed studies on their solution behavior, physicochemical properties affecting the pharmacokinetics including their affinity towards endogenous bioligands. This kind of information may help to predict and control the fate of pharmaceuticals in the biofluids. The main objective of this work was to characterize the solution speciation and albumin binding properties of 
RhCp* complexes of two (N,N) donor ligands (bpy and en) in comparison with biologically more active complexes containing (O,O) donor set. Stoichiometry and stability of $\mathrm{RhCp}$ * complexes of en and bpy were determined in aqueous solution via a combined approach using $\mathrm{pH}$ potentiometry, ${ }^{1} \mathrm{H}$ NMR spectroscopy, and UV-Vis spectrophotometry in the absence and presence of chloride ions. RhCp* forms prominently high stability complexes with bpy and en. [RhCp*(L)Z] $\left(\mathrm{Z}=\mathrm{H}_{2} \mathrm{O} / \mathrm{Cl}^{-}\right)$species predominate at physiological $\mathrm{pH}$, and based on the stability constants their decomposition cannot occur even at low micromolar concentrations. Moreover, mixed hydroxido $\operatorname{species~}[\mathrm{RhCp} *(\mathrm{~L})(\mathrm{OH})]^{+}$are formed only in the basic $\mathrm{pH}$ range. Additionally, the structure of the complex $\left[\mathrm{RhCp}^{*}(\mathrm{en}) \mathrm{Cl}\right] \mathrm{ClO}_{4}$ was characterized in solid form by singlecrystal X-ray diffraction analysis. [RhCp*(bpy)Z] possesses higher stability at $\mathrm{pH} 7.4$ than [RhCp*(en)Z], and their stability considerably exceeds that of the hydroxypyr(idin)one complexes with $(\mathrm{O}, \mathrm{O})$ donor sets. Chloride ions act as competitive ligands and are able to suppress the formation and the hydrolysis of $[\mathrm{RhCp} *(\mathrm{~L}) \mathrm{Z}]$ complexes to some extent. $\mathrm{H}_{2} \mathrm{O} / \mathrm{Cl}^{-}$co-ligand exchange equilibrium constants for the $\left[\mathrm{RhCp}^{*}(\mathrm{~L})\left(\mathrm{H}_{2} \mathrm{O}\right)\right]^{+}$complexes of en and bpy were also determined, which represent much stronger ability to retain the chloride at the third coordination site compared with the species containing the bidentate O-donor ligands. This strong chloride ion affinity most probably contributes to the diminished antiproliferative effect of the studied complexes with $(\mathrm{N}, \mathrm{N})$ donor set and to the decreased catalytic activity of the bpy complex.

Since binding of metallodrugs to the blood transport protein HSA has a profound influence on the biodistribution, interaction of HSA with the $\mathrm{RhCp}^{*}$ complexes of en, bpy and the $(\mathrm{O}, \mathrm{O})$ donor dhp was investigated. A panel of methods comprising ${ }^{1} \mathrm{H}$ NMR spectroscopy, ultrafiltration/UV-Vis and spectrofluorometry was used involving fluorescent site markers (WF, DG) and amino acid side chain models. The interaction between HSA and $\mathrm{RhCp}^{*}$ or its dhp complex reaches equilibrium quite fast, while binding of the en and bpy complexes was considerably slower. The metal ion alone is able to bind on at least 8 sites involving binding events at sites I and II based on the results of Trp quenching and site marker displacement reactions. The extent of the binding of the dhp complex on these sites is similar to that of the organometallic ion alone, and according to the results of ${ }^{1} \mathrm{H}$ NMR spectroscopic and ultrafiltration measurements the complex decomposes at low excess to the protein, and free ligand is liberated. These findings suggest that the binding takes place via coordination (covalent) bonds. Formation of ternary complexes is probable, without cleavage of the Rh-dhp bonds, via binding to amino acid side chains of the protein at the 
third coordination site parallel to the dissociative mechanism at elevated excess of the complex. In the case of the much higher stability complexes containing the $(\mathrm{N}, \mathrm{N})$ donor set binding of 4-5 complexes on the protein is feasible, although not at sites I and II. The en and bpy complexes do not lose their original ligands upon HSA binding. Similarly to organoruthenium complexes, binding of the studied RhCp* complexes to the imidazole nitrogen of His is the most favored thermodynamically. Ternary adducts are formed most probably by the coordination of nitrogen atoms of surface His residues at the third coordination site of the RhCp* complex, while the metal ion, losing the original ligand, is able to bind covalently into the deep hydrophobic pockets of site I and II.

\section{Abbreviations}

$\begin{array}{ll}\text { Cp* } & \text { pentamethylcyclopentadienyl } \\ \text { bpy } & \text { 2,2'-bipyridine } \\ \text { DG } & \text { dansylglycine } \\ \text { dhp } & \text { 1,2-dimethyl-3-hydroxy-pyrid-4(1H)-one (deferiprone) } \\ \text { DSS } & \text { 4,4-dimethyl-4-silapentane-1-sulfonic acid } \\ \text { en } & \text { ethylenediamine } \\ \text { HMM } & \text { high molecular mass } \\ \text { HSA } & \text { human serum albumin } \\ \text { LMM } & \text { low molecular mass } \\ \lambda_{\text {EM }} & \text { fluorescence emission wavelength } \\ \lambda_{\text {EX }} & \text { fluorescence excitation wavelength } \\ \text { maltol } & \text { 3-hydroxy-2-methyl-pyran-4(1H)-one }\end{array}$




$\begin{array}{ll}\text { PBS } & \text { phosphate buffered saline } \\ \text { PBS } & \text { modified phosphate buffered saline } \\ \text { phen } & \text { 1,10-phenanthroline } \\ \text { pic } & \text { pyridine-2-carboxylic acid, 2-picolinic acid } \\ \text { pp } & \text { polypyridyl } \\ \text { PTA } & \text { 1,3,5-triaza-7-phosphatricyclo-[3.3.1.1]decane } \\ \text { RhCp* } & \left(\eta^{5} \text {-pentamethylcyclopentadienyl) rhodium(III) }\right. \\ \text { UV-Vis } & \text { UV-visible } \\ \text { WF } & \text { warfarin }\end{array}$

\section{Acknowledgements}

This work was supported by the Hungarian Research Foundation OTKA project PD103905. We thank Ms. Gabriella Kiss for conducting some measurements.

\section{Appendix A. Supplementary data}

Supplementary data associated with this article can be found, in the online version, at...

\section{References}

[1] M.A. Jakupec, M. Galanski, V.B. Arion, C.G. Hartinger, B.K. Keppler, Dalton Trans. (2008) 183-194.

[2] G. Süss-Fink, Dalton Trans. 39 (2010) 1673-1688.

[3] G. Gasser, I. Ott, N. Metzler-Nolte, J. Med. Chem. 54 (2011) 3-25.

[4] E. Alessio, G. Mestroni, A. Bergamo, G. Sava, Curr. Top. Med. Chem. 4 (2004) 1525-1535. 
[5] C.G. Hartinger, M.A. Jakupec, S. Zorbas-Seifried, M. Groessl, A. Egger, W. Berger, H. Zorbas, P.J. Dyson, B.K. Keppler, Chem. Biodivers. 5 (2008) 2140-2155.

[6] N.R. Dickson, S.F. Jones, H.A. Burris, R.K. Ramanathan, G.J. Weiss, J.R. Infante, J.C. Bendell, W. McCulloch, D.D. Von Hoff, J. Clin. Oncol. 29 (2011) suppl., abstr. 2607.

[7] J.J. Soldevila-Barreda, I. Romero-Canelón, A. Habtemariam, P.J. Sadler, Nat. Commun. 6 (2015) Article number: 6582.

[8] L. Dadci, H. Elias, U. Frey, A. Hörnig, U. Koelle, A.E. Merbach, H. Paulus, J.S. Schneider, Inorg. Chem. 34 (1995) $306-315$.

[9] Y. Geldmacher, M. Oleszak, W.S. Sheldrick, Inorg. Chim. Acta 393 (2012) 84-102.

[10] A. Dorcier, W.H. Ang, S. Bolano, L. Gonsalvi, L. Juillerat-Jeannerat, G. Laurenczy, M. Peruzzini, A.D. Phillips, F. Zanobini, P.J. Dyson, Organometallics 25 (2006) 4090-4096.

[11] O. Dömötör, S. Aicher, M. Schmidlehner, M.S. Novak, A. Roller, M.A. Jakupec, W. Kandioller, C.G. Hartinger, B.K. Keppler, É.A. Enyedy, J. Inorg. Biochem. 134 (2014) 57-65.

[12] É.A. Enyedy, O. Dömötör, C.M. Hackl, A. Roller, M.S. Novak, M.A. Jakupec, B.K. Keppler, W. Kandioller, J. Coord. Chem. 68 (2015) $1583-1601$.

[13] M. Schmidlehner, V. Pichler, A. Roller, M.A. Jakupec, Wolfgang Kandioller, B.K. Keppler, J. Organomet. Chem. 782 (2015) 69-76.

[14] Y. Geldmacher, K. Splith, I. Kitanovic, H. Alborzinia, S. Can, R. Rubbiani, M.A. Nazif, P. Wefelmeier, A. Prokop, I. Ott, S. Wölfl, I. Neundorf, W.S. Sheldrick, J. Biol. Inorg. Chem. 17 (2012) 631-646.

[15] Y. Geldmacher, R. Rubbiani, P. Wefelmeier, A. Prokop, I. Ott, W.S. Sheldrick, J. Organomet. Chem. 696 (2011) $1023-1031$.

[16] M.A. Nazif, R. Rubbiani, H. Alborzinia, I. Kitanovic, S. Wolfl, I. Ott, W.S. Sheldrick, Dalton Trans. 41 (2012) $5587-5598$.

[17] M.A. Scharwitz, I. Ott, Y. Geldmacher, R. Gust, W.S. Sheldrick, J. Organomet. Chem. 693 (2008) 2299-2309.

[18] R.E. Morris, R.E. Aird, P.S. Murdoch, H. Chen, J. Cummings, N.D. Hughes, S. Parsons, A. Parkin, G. Boyd, D.I. Jodrell, P.J. Sadler, J. Med. Chem. 44 (2001) 3616-3621. 
[19] A. Walcarius, R. Nasraoui, Z. Wang, F. Qu, V. Urbanova, M. Etienne, M. Göllü, A.S. Demir, J. Gajdzik, R. Hempelmann, Bioelectrochemistry 82 (2011) 46-54.

[20] M. Poizat, I.W.C.E. Arends, F. Hollmann, J. Mol. Catal B: Enzym. 63 (2010) 149-156.

[21] J.D. Blakemore, E.S. Hernandez, W. Sattler, B.M. Hunter, L.M. Henling, B.S. Brunschwig, H.B. Gray, Polyhedron 84 (2014) 14-18.

[22] J. Lutz, F. Hollmann, T.V. Ho, A. Schnyder, R.H. Fish, A. Schmid, J. Organomet. Chem. 689 (2004) $4783-4790$.

[23] F. Hollmann, B. Witholt, A. Schmid, J. Mol. Catal. B: Enzym. 19-20 (2003) 167-176.

[24] K. Vuorilehto, S. Lütz, C. Wandrey, Bioelectrochemistry 65 (2004) 1-7.

[25] H.C. Lo, C. Leiva, O. Buriez, J.B. Kerr, M.M. Olmstead, R.H. Fish, Inorg. Chem. 40 (2001) 6705-6716.

[26] M.S. Eisen, A. Haskel, H. Chen, M.M. Olmstead, D.P. Smith, M.F. Maestre, R.H. Fish, Organometallics 14 (1995) $2806-2812$.

[27] S. Ogo, H. Chen, M.M. Olmstead, R.H. Fish, Organometallics 15 (1996) 2009-2013.

[28] D.P. Smith, H. Chen, Seiji Ogo, A.I. Elduque, M. Eisenstein, M.M. Olmstead, R.H. Fish, Organometallics 33 (2014) $2389-2404$.

[29] A. Nutton, P.M. Baily, P.M. Maitlis, J. Chem. Soc. Dalton Trans. (1981) 1997-2002.

[30] L. Booth, R.N. Haszeldine, M. Hill. J. Chem. Soc. A (1969) 1299-1303.

[31] P. Gans, A. Sabatini, A. Vacca, Talanta 43 (1996) 1739-1753.

[32] G.H. Beaven, S. Chen, A. D’Albis, W.B. Gratzer, Eur. J. Biochem. 42 (1974) 539-546.

[33] H.M. Irving, M.G. Miles, L.D. Pettit, Anal. Chim. Acta 38 (1967) 475-488.

[34] SCQuery, The IUPAC Stability Constants Database, Academic Software (Version 5.5), Royal Society of Chemistry, $1993-2005$.

[35] L. Zékány, I. Nagypál, in: Computational Methods for the Determination of Stability Constants (Ed.: D. L. Leggett), Plenum Press, New York, 1985, pp. 291-353.

[36] É.A. Enyedy, L. Horváth, A. Hetényi, T. Tuccinardi, C.G. Hartinger, B.K. Keppler, T. Kiss, Bioorg. Med. Chem. 19 (2011) $4202-4210$.

[37] O. Dömötör, C.G. Hartinger, A.K. Bytzek, T. Kiss, B.K. Keppler, E.A. Enyedy, J. Biol. Inorg. Chem. 18 (2013) 9-17. 
[38] M.R. Pressprich, J. Chambers, SAINT + Integration Engine, Program for Crystal Structure Integration, Bruker Analytical X-ray systems: Madison, 2004

[39] G.M. Sheldrick, Acta Cryst. A64 (2008) 112-122.

[40] O.V. Dolomanov, L.J. Bourhis, R.J. Gildea, J.A.K. Howard, H. Puschmann, J. Appl. Cryst. 42 (2009) 339-341.

[41] C.B. Hübschle, G.M. Sheldrick, B. Dittrich, J. Appl. Cryst. 44 (2011) 1281-1284.

[42] L.J. Farrugia, J. Appl. Cryst. 30 (1997) 565.

[43] International Tables for X-ray Crystallography. Kluwer Academic Press: Dordrecht, The Netherlands, 1992; Vol. C.

[44] E. Farkas, É.A. Enyedy, G. Micera, E. Garibba, Polyhedron 19 (2000) 1727-1736.

[45] T. Jakusch, P. Buglyó, A.I. Tomaz, J.C. Pessoa, T. Kiss, Inorg. Chim. Acta 339 (2002) 119-128.

[46] M.S. Mohan, D. Bancroft, E.H. Abbott, Inorg. Chem. 18 (1979) 2468-2472.

[47] A. Avdeef, Anal. Chim. Acta 148 (1983) 237-244.

[48] L. Bíró, E. Farkas, P. Buglyó, Dalton Trans. 41 (2012) 285-291.

[49] A.F.A. Peacock, A. Habtemariam, S.A. Moggach, A. Prescimone, S. Parsons, P.J. Sadler, Inorg. Chem. 46 (2007) $4049-4059$.

[50] M. Melchart, A. Habtemariam, O. Novakova, S.A. Moggach, F.P.A. Fabbiani, S. Parsons, V. Brabec, P.J. Sadler, Inorg. Chem. 46 (2007) 8950-8962.

[51] F. Wang, H. Chen, S. Parsons, I.D.H. Oswald, J.E. Davidson, P.J. Sadler, Chem. Eur. J. 9 (2003) 5810-5820.

[52] A. M. Pizarro, A. Habtemariam, P.J. Sadler, In: Medicinal Organometallic Chemistry (Topics in Organometallic Chemistry), 1st ed., (Eds. G. Jaouen, N. Metzler-Nolte), Springer-Verlag: Heidelberg, Germany, Vol. 32, pp 21-56. (2010).

[53] R.B. Martin, In: Cisplatin: Chemistry and Biochemistry of a Leading Anticancer Drug, (Ed. B. Lippert), VHCA \& Wiley-VCH: Zürich, Switzerland, pp 181-205 (1999).

[54] G. Garcia, G. Sánchez, I. Romero, I. Solano, M.D. Santana, G. Lopez, J. Organomet. Chem. 408 (1991) $241-246$.

[55] M. Scharwitz, T. van Almsick, W.S. Sheldrick, Acta Cryst.(2007). E63, m1469-m1470. 
[56] W.R. Harris, K.N. Raymond, F.L. Weitl, J. Am. Chem. Soc. 103 (1981) 2667-2675.

[57] Z. Liu, A. Habtemariam, A.M. Pizarro, S.A. Fletcher, A. Kisova, O. Vrana, L. Salassa, P.C.A. Bruijnincx, G.J. Clarkson, V. Brabec, P.J. Sadler, J. Med. Chem. 54 (2011) 3011-3026.

[58] A. Habtemariam, M.Melchart, R. Fernandez, S. Parsons, I.D.H. Oswald, A. Parkin, F.P.A. Fabbiani, J.E. Davidson, A. Dawson, R.E. Aird, D.I. Jodrell, P.J. Sadler, J. Med. Chem. 49 (2006) 6858-6868.

[59] F. Kratz, J. Control. Release 132 (2008) 171-183.

[60] G. Fanali, A. Masi, V. Trezza, M. Marino, M. Fasano, P. Ascenzi, Mol. Aspects. Med. 33 (2012) 209-290.

[61] G. Sudlow, D.J. Birkett, D.N. Wade, Mol. Pharmacol. 11 (1975) 824-832.

[62] W. Bal, M. Sokołowska, E. Kurowska, P. Faller, Biochim. Biophys. Acta 1830 (2013) 5444-5455.

[63] T. Peters, All About Albumin: Biochemistry, Genetics and Medical Applications, Academic Press, San Diego (1996)

[64] W. Hu, Q. Luo, X. Ma, K. Wu, J. Liu, Y. Chen, S. Xiong, J. Wang, P.J. Sadler, F. Wang, Chem. Eur. J. 15 (2009) $6586-6594$.

[65] A.R. Timerbaev, C.G. Hartinger, S.S. Aleksenko, B.K. Keppler, Chem. Rev. 106 (2006) 2224-2248.

[66] H.B. Albada, F. Wieberneit, I. Dijkgraaf, J.H. Harvey, J.L. Whistler, R. Stoll, N. Metzler-Nolte, R.H. Fish, J. Am. Chem. Soc. 134 (2012) 10321-10324.

[67] Zs. Bihari, Z. Nagy, P. Buglyó, J. Organomet. Chem. 782 (2015) 82-88. 


\section{Table 1}

Proton dissociation constants $\left(\mathrm{p} K_{\mathrm{a}}\right)$ of en and bpy and overall stability constants $(\log \beta)$ and $\mathrm{p} K_{\mathrm{a}}$ values of their $[\mathrm{RhCp} *(\mathrm{~L}) \mathrm{Z}]$ complexes in chloride-free and chloride-containing aqueous solutions determined by various methods, and $\mathrm{H}_{2} \mathrm{O} / \mathrm{Cl}^{-}$exchange constants (log $K$ ) for the $\left[\mathrm{RhCp} *(\mathrm{~L})\left(\mathrm{H}_{2} \mathrm{O}\right)\right]^{2+}$ complexes $\left\{T=25^{\circ} \mathrm{C} ; I=0.20 \mathrm{M} ; \mathrm{Z}=\mathrm{H}_{2} \mathrm{O}\right.$ or $\left.\mathrm{Cl}^{-}\right\} .^{\text {a }}$

\begin{tabular}{|c|c|c|c|c|c|c|c|c|}
\hline \multirow[b]{3}{*}{ pK $K_{1}$ (ligand) } & \multicolumn{4}{|c|}{ en } & \multicolumn{4}{|c|}{ bpy } \\
\hline & \multicolumn{2}{|c|}{$0.2 \mathrm{M} \mathrm{KNO}_{3}$} & \multicolumn{2}{|c|}{$0.2 \mathrm{M} \mathrm{KCl}$} & \multicolumn{2}{|c|}{$0.2 \mathrm{M} \mathrm{KNO}_{3}$} & \multicolumn{2}{|c|}{$0.2 \mathrm{M} \mathrm{KCl}$} \\
\hline & $7.25(1)$ & pH-metry & $7.19(1)$ & pH-metry & $4.41(2)$ & $p H$-metry & $4.52(1)$ & pH-metry \\
\hline & & & 7.21(1) & ${ }^{1} H N M R$ & & & $4.53(1)$ & ${ }^{1} H N M R$ \\
\hline \multirow[t]{2}{*}{$\mathrm{p} K_{2}$ (ligand) } & $10.01(1)$ & pH-metry & $9.98(1)$ & pH-metry & - & & - & \\
\hline & & & $10.04(1)$ & ${ }^{1} H N M R$ & & & & \\
\hline $\log \beta\left[\mathbf{R h C p}^{*}(\mathbf{L}) \mathrm{Z}\right]$ & $15.04(5)$ & pH-metry & $14.48(1)$ & pH-metry & $>12.95^{\mathrm{b}}$ & estimated & $12.95(6)^{\mathrm{c}}$ & $U V-v i s$ \\
\hline \multirow[t]{3}{*}{$\mathrm{p} K_{a}[\mathrm{RhCp} *(\mathrm{~L}) \mathrm{Z}]$} & $9.58(2)$ & ${ }^{1} H N M R$ & $11.05(1)$ & $U V-v i s$ & $8.66(3)$ & $U V-v i s$ & $10.39(2)$ & $U V-v i s$ \\
\hline & & & & & $8.61(2)$ & ${ }^{1} H N M R$ & $10.39(5)$ & ${ }^{1} H N M R$ \\
\hline & & & & & $8.41(3)$ & pH-metry & $10.25(5)$ & pH-metry \\
\hline species at pH $7.4^{\mathrm{d}}$ & $99 \%[\mathrm{RhCp} *$ & $\left.(\mathrm{L})\left(\mathrm{H}_{2} \mathrm{O}\right)\right]^{2+}$ & $97 \%[\mathrm{RhC}$ & $\left.\mathrm{p}^{*}(\mathrm{~L})(\mathrm{Cl})\right]^{+}$ & $94 \%[\mathrm{RhCp}$ & $\left.\mathrm{L})\left(\mathrm{H}_{2} \mathrm{O}\right)\right]^{2+}$ & $99 \%[\mathrm{RhC}$ & $*(\mathrm{~L})(\mathrm{Cl})]^{+}$ \\
\hline
\end{tabular}




$1 \%[\mathrm{RhCp} *(\mathrm{~L})(\mathrm{OH})]^{+} \quad 3 \%\left[\mathrm{RhCp}^{*}(\mathrm{~L})\left(\mathrm{H}_{2} \mathrm{O}\right)\right]^{2+} \quad 6 \%\left[\mathrm{RhCp}^{*}(\mathrm{~L})(\mathrm{OH})\right]^{+} \quad 1 \%\left[\mathrm{RhCp} *(\mathrm{~L})\left(\mathrm{H}_{2} \mathrm{O}\right)\right]^{2+}$

${ }^{a}$ Charges of the complexes are omitted for simplicity. Standard deviations (SD) are in parenthesis. $\mathrm{Z}=\mathrm{H}_{2} \mathrm{O}$ or $\mathrm{Cl}^{-}$for chloride-containing samples; $\mathrm{Z}=\mathrm{H}_{2} \mathrm{O}$ for chloride-free media. Hydrolysis products of the organometallic cation: $\log \beta\left[\left(\mathrm{RhCp}^{*}\right)_{2} \mathrm{H}_{-2}\right]=-11.12, \log \beta\left[\left(\mathrm{RhCp}^{*}\right)_{2} \mathrm{H}_{-3}\right]=$ -19.01 at $I=0.20 \mathrm{M}(\mathrm{KCl})$ and $\log \beta\left[\left(\mathrm{RhCp}^{*}\right)_{2} \mathrm{H}_{-2}\right]=-8.53, \log \beta\left[\left(\mathrm{RhCp}^{*}\right)_{2} \mathrm{H}_{-3}\right]=-14.26$ at $I=0.20 \mathrm{M}\left(\mathrm{KNO}_{3}\right)$ taken from Ref. [11]. ${ }^{\mathrm{b}} \mathrm{The}$ strong absorption of the $\mathrm{NO}_{3}{ }^{-}$hinders its determination by UV-Vis spectrophotometry. ${ }^{\mathrm{c}}$ Determined by UV-Vis via competition studies. ${ }^{\mathrm{d}}$ Calculated at $\mathrm{pH}=7.4, c_{\mathrm{L}}=c_{\mathrm{RhCp}^{*}}=1 \mu \mathrm{M}$. ${ }^{\mathrm{e}}$ For the $\left[\mathrm{RhCp} *(\mathrm{~L})\left(\mathrm{H}_{2} \mathrm{O}\right)\right]^{2+}+\mathrm{Cl}^{-} \rightleftharpoons\left[\mathrm{RhCp}^{*}(\mathrm{~L})(\mathrm{Cl})\right]^{+}+\mathrm{H}_{2} \mathrm{O}$ equilibrium determined by $\mathrm{UV}-\mathrm{Vis}$ at $\mathrm{pH}=7.4$ and at various chloride total concentrations. 



\section{Table 2}

Distribution $(\%)$ of $\mathrm{RhCp}^{*}$ in the $\left[\mathrm{RhCp}^{*}\left(\mathrm{H}_{2} \mathrm{O}\right)_{3}\right]^{2+}$ - ligand A - ligand B $(1: 1: 1)$ ternary systems on the basis of the ${ }^{1} \mathrm{H}$ NMR peak integrals of the $\mathrm{Cp}^{*}$ methyl protons. Ligand $\mathrm{A}$ : en, bpy or dhp; ligand B as protein binding site model (N-MeIm, N-ACMe or N-AM). $\left\{c_{R h C p^{*}}=\right.$ $c_{\text {ligand } A}=c_{\text {ligand } B}=0.75 \mathrm{mM} ; \mathrm{pH}=7.4$ (PBS' buffer); $T=25^{\circ} \mathrm{C}$; incubation time $\left.=24 \mathrm{~h}\right\}$.

\begin{tabular}{|c|c|c|c|c|}
\hline $\mathbf{A}$ & $\overline{\mathbf{B}}$ & {$\left[\mathrm{RhCp}^{*}(\mathrm{~A})\right]$} & {$\left[\mathrm{RhCp}^{*}(\mathrm{~B})\right]$} & {$\left[\mathrm{RhCp}^{*}(\mathrm{~A})(\mathrm{B})\right]$} \\
\hline \multirow{3}{*}{ ప } & N-MeIm & 22 & 5 & 73 \\
\hline & N-ACMe & 100 & 0 & 0 \\
\hline & N-AM & 100 & 0 & 0 \\
\hline \multirow{3}{*}{$\frac{a}{2}$} & N-MeIm & 14 & 0 & 86 \\
\hline & N-ACMe & 92 & 0 & 8 \\
\hline & $\mathbf{N}-\mathbf{A M}$ & 67 & 0 & 33 \\
\hline \multirow{3}{*}{$\hat{z}$} & N-MeIm & 0 & 9 & 91 \\
\hline & N-ACMe & 100 & 0 & 0 \\
\hline & N-AM & 0 & 10 & 90 \\
\hline
\end{tabular}




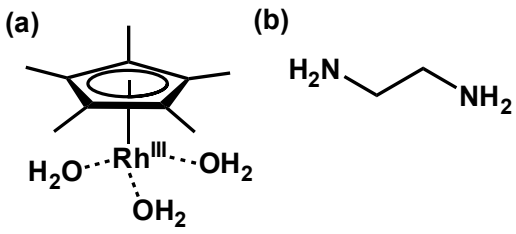

(c)

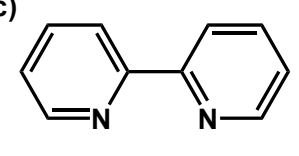

Chart 1 Chemical structures of $\left[\mathrm{RhCp}^{*}\left(\mathrm{H}_{2} \mathrm{O}\right)_{3}\right]^{2+}(\mathrm{a})$, en (b) and bpy (c).

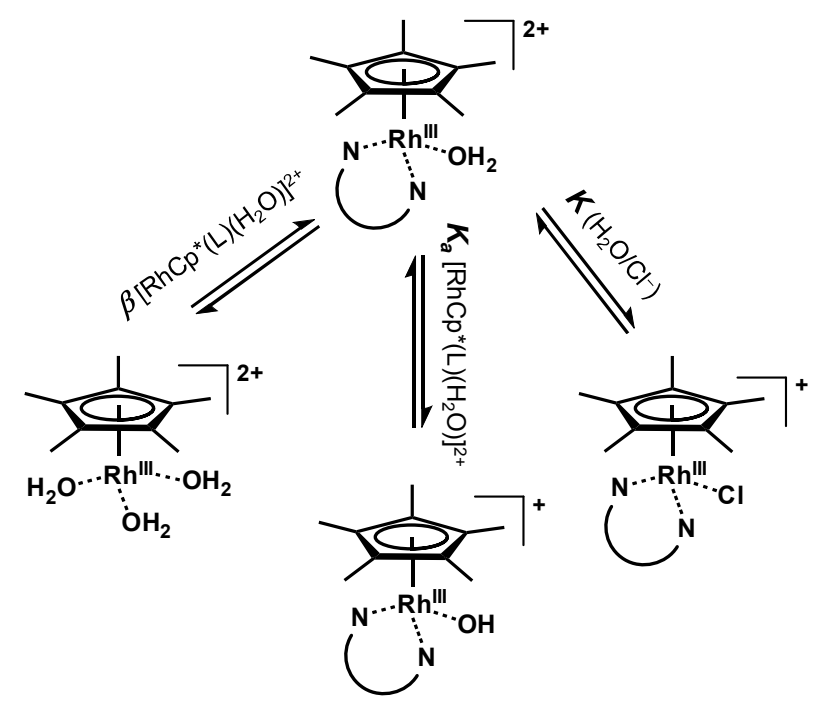

Chart 2 Complexation and co-ligand exchange equilibrium processes for the $\left[\mathrm{RhCp} *(\mathrm{~L})\left(\mathrm{H}_{2} \mathrm{O}\right)\right]^{2+}$ species.<smiles>Cn1ccnc1</smiles>

N-Melm

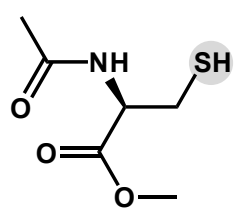

$\mathrm{N}-\mathrm{ACMe}$<smiles>CSCC[C@H](NC(C)=O)C(=O)O</smiles>

N-AM

Chart 3 Chemical structures of protein binding site model compounds. 

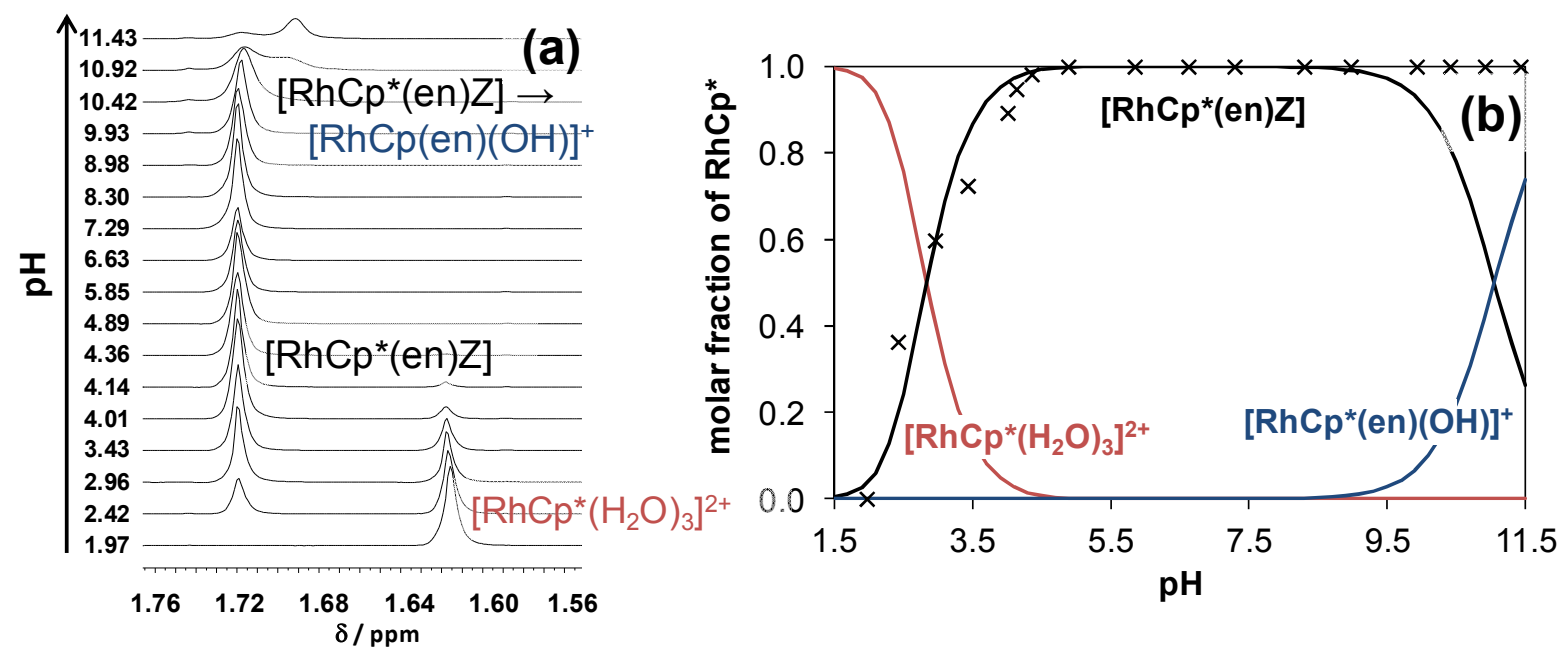

Fig. 1 High field region of the ${ }^{1} \mathrm{H}$ NMR spectra of the $\left[\mathrm{RhCp} *\left(\mathrm{H}_{2} \mathrm{O}\right)_{3}\right]^{2+}-$ en $(1: 1)$ system in chloridecontaining aqueous solution recorded at indicated $\mathrm{pH}$ values (a). Concentration distribution curves (solid lines) for the same system calculated on the basis of the stability constants determined and molar fractions of the bound $\mathrm{RhCp}^{*}(\times)$ based on the ${ }^{1} \mathrm{H}$ NMR peak integrals of the Cp* methyl protons (b). $\left\{c_{R h C p^{*}}=c_{e n}=1 \mathrm{mM} ; \mathrm{T}=25^{\circ} \mathrm{C} ; \mathrm{I}=0.20 \mathrm{M}(\mathrm{KCl}) ; 10 \% \mathrm{D}_{2} \mathrm{O} ; \mathrm{Z}=\mathrm{H}_{2} \mathrm{O}\right.$ or $\left.\mathrm{Cl}^{-}\right\}$.

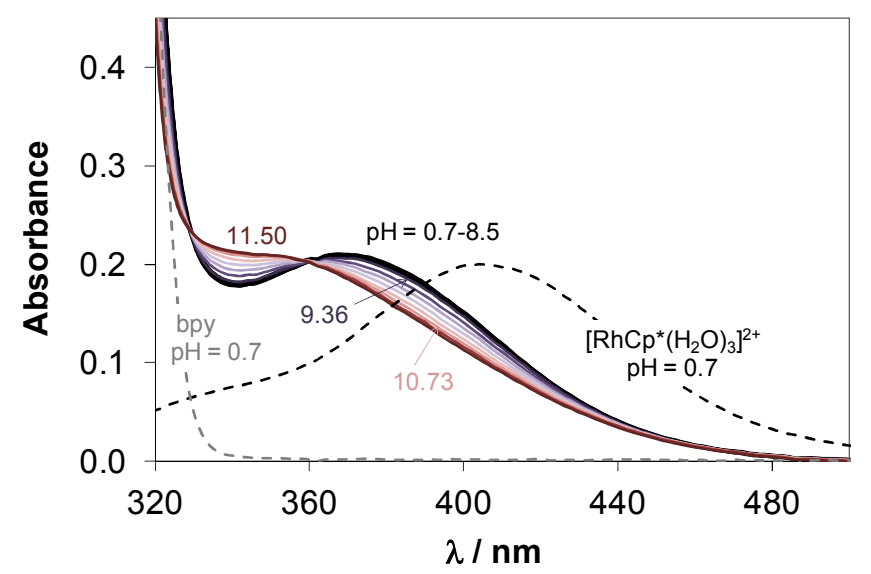

Fig. 2 UV-Vis spectra of the $\left[\mathrm{RhCp}^{*}\left(\mathrm{H}_{2} \mathrm{O}\right)_{3}\right]^{2+}-$ bpy $(1: 1)$ system (solid lines) in chloride-containing aqueous solution recorded at various pH values. Spectra of $\left[\mathrm{RhCp} *\left(\mathrm{H}_{2} \mathrm{O}\right)_{3}\right]^{2+}$ (dashed black line) and bpy (dashed grey line) are shown for comparison recorded at $\mathrm{pH}=0.7$. Inset shows the absorbance values measured for the $\left[\mathrm{RhCp} *\left(\mathrm{H}_{2} \mathrm{O}\right)_{3}\right]^{2+}-$ bpy $(1: 1)$ system at $366 \mathrm{~nm}$ plotted against the $\mathrm{pH}$. $\left\{c_{R h C p^{*}}\right.$ $\left.=c_{b p y}=100 \mu M ; T=25{ }^{\circ} \mathrm{C} ; I=0.20 \mathrm{M}(\mathrm{KCl})\right\}$. 


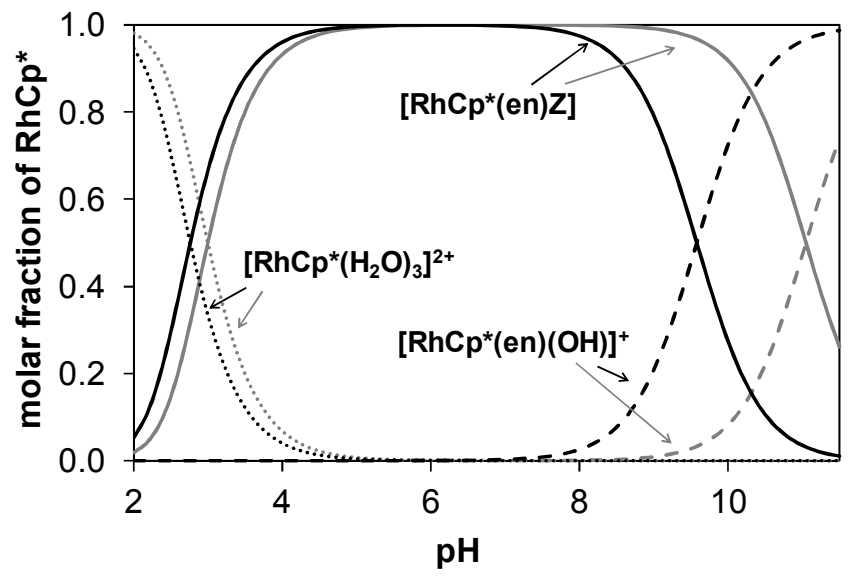

Fig. 3 Concentration distribution curves of the $\left[\mathrm{RhCp} *\left(\mathrm{H}_{2} \mathrm{O}\right)_{3}\right]^{2+}-$ en $(1: 1)$ system in chloride-free (black lines) and chloride-containing (grey lines) aqueous solutions as a function of $\mathrm{pH}$ calculated with the aid of the stability constants determined. $\left\{c_{R h C p^{*}}=c_{e n}=1 \mathrm{mM} ; \mathrm{T}=25^{\circ} \mathrm{C} ; \mathrm{I}=0.20 \mathrm{M}\left(\mathrm{KNO}_{3} \mathrm{or}\right.\right.$ $\mathrm{KCl}) ; \mathrm{Z}=\mathrm{H}_{2} \mathrm{O}$ or $\left.\mathrm{Cl}^{-}\right\}$.

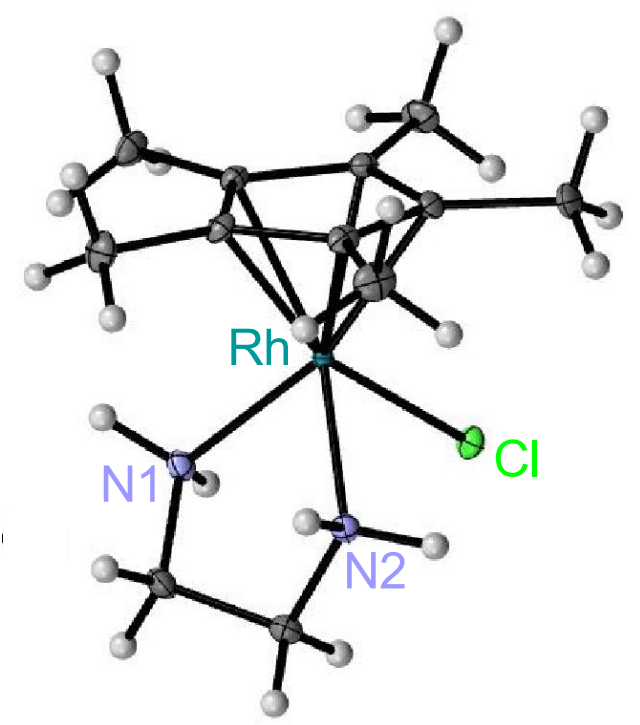

Fig. 4 ORTEP view of $\left[\mathrm{RhCp}^{*}(\mathrm{en}) \mathrm{Cl}\right] \mathrm{ClO}_{4} \cdot 2 \mathrm{H}_{2} \mathrm{O}(\mathbf{1})$ with ellipsoids drawn at $50 \%$ probability level. Counter ion and solvent molecules are omitted for clarity. Selected bond distances $(\AA)$ and angles (deg): Rh1-N1: 2.1453(15); Rh1-N2: 2.1235(16); Rh1-Cl1: 2.4339(5); Rh1-ring centroid: 1.76303(8); N2-Rh1-N1: 80.23(6) ${ }^{\circ}$; N1-Rh1-C11: 88.09(4) ${ }^{\circ}$; N2-Rh1-Cl1: 85.41(4) . 


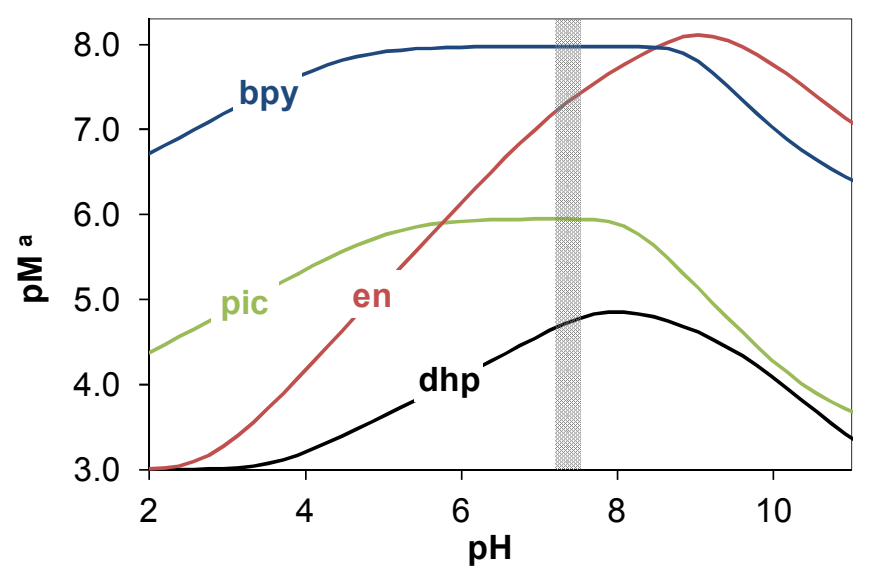

Fig. $5 \mathrm{pH}$-dependence of the negative logarithm of the summed equilibrium concentrations of the free RhCp* cation and its hydroxido species (pM) calculated for the $\left[\mathrm{RhCp}^{*}\left(\mathrm{H}_{2} \mathrm{O}\right)_{3}\right]^{2+}-\mathrm{bpy} / \mathrm{en} / \mathrm{pic} / \mathrm{dhp}$ systems under identical conditions. $\left\{c_{R h C p^{*}}=c_{L}=1 \mathrm{mM} ; \mathrm{T}=25^{\circ} \mathrm{C} ; \mathrm{I}=0.20 \mathrm{M}(\mathrm{KCl})\right\}$. Calculations for the dhp- and pic-containing systems are based on data from Ref. [12]. ${ }^{\mathrm{a}} \mathrm{pM}=$ $-\log \left(\left[\mathrm{RhCp}^{*}\right]+\left[\left(\mathrm{RhCp}^{*}\right)_{2}(\mathrm{OH})_{\mathrm{i}}\right]\right)$, where $\mathrm{i}=2$ or 3 . 


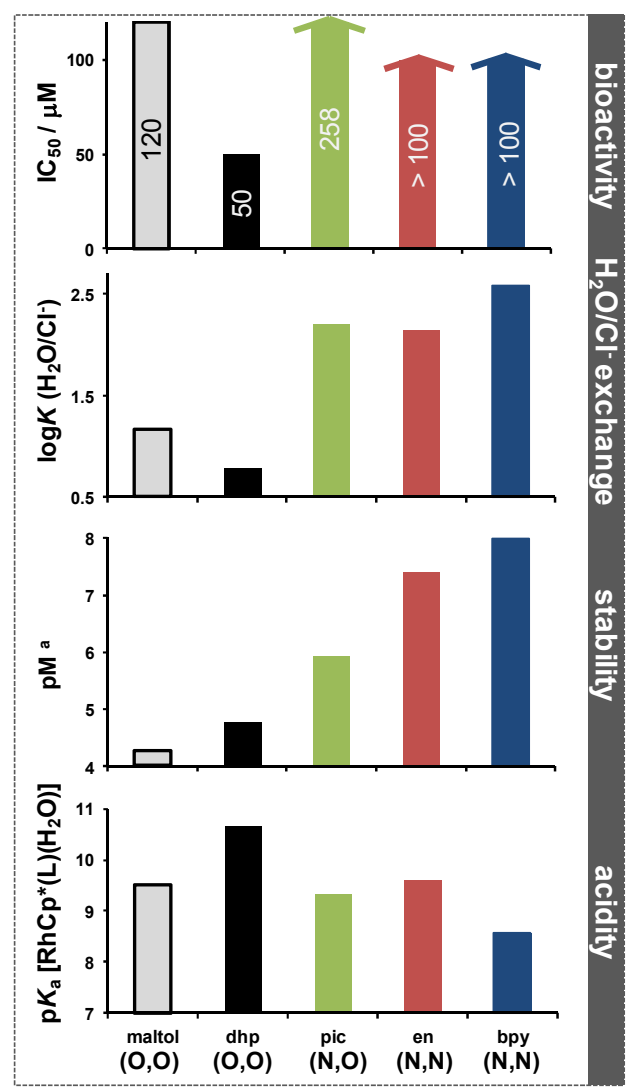

Fig. $6 \mathrm{p} K_{\mathrm{a}}\left[\mathrm{RhCp} *(\mathrm{~L})\left(\mathrm{H}_{2} \mathrm{O}\right)\right], \mathrm{pM}, \log K\left(\mathrm{H}_{2} \mathrm{O} / \mathrm{Cl}^{-}\right)$values and cytotoxicity data for the $\mathrm{RhCp}$ * complexes of maltol, dhp, pic, en and bpy. $\mathrm{p} K_{\mathrm{a}}, \mathrm{pM}, \log K$ and $\mathrm{IC}_{50}$ (against CH1/PA-1 ovarian adenocarcinoma cell lines) values for maltol, dhp and pic complexes are taken from Ref. [11,12]. $\mathrm{IC}_{50}$ values (against MCF-7 breast cancer cell lines) for complexes of en and bpy are taken from Ref. [17]. ${ }^{\mathrm{a}} \mathrm{pM}=-\log \left(\left[\mathrm{RhCp}^{*}\right]+\left[\left(\mathrm{RhCp}^{*}\right)_{2}(\mathrm{OH})_{\mathrm{i}}\right]\right)$, where $\mathrm{i}=2$ or 3 , and values are calculated under identical conditions: $\left\{c_{R h C p^{*}}=c_{L}=1 \mathrm{mM} ; \mathrm{pH}=7.4 ; \mathrm{T}=25{ }^{\circ} \mathrm{C} ; \mathrm{I}=0.20 \mathrm{M}(\mathrm{KCl})\right\}$. 
(a)

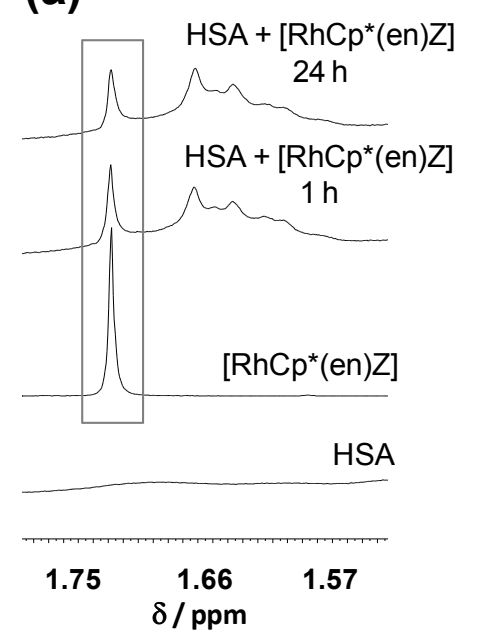

(b)

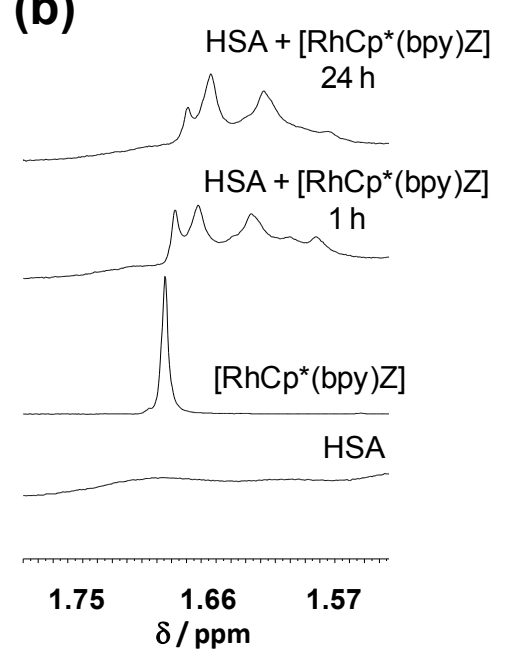

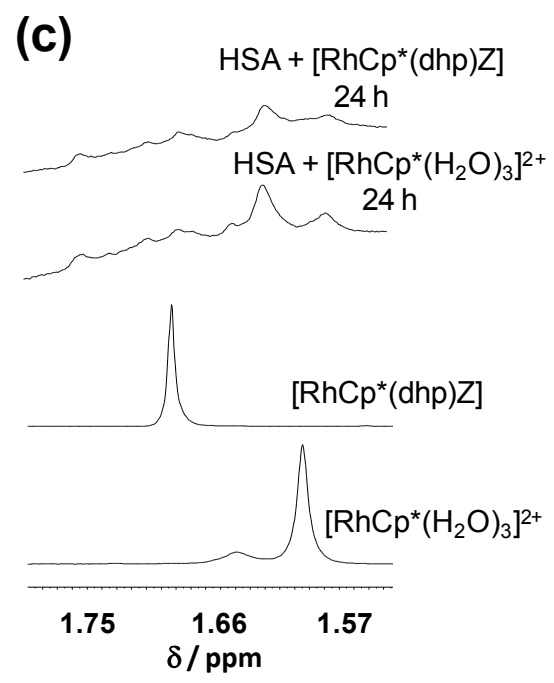

Fig. 7 High field regions of the ${ }^{1} \mathrm{H}$ NMR spectra recorded for the HSA - [RhCp*(en)Z] (a), HSA $[\mathrm{RhCp} *(\mathrm{bpy}) \mathrm{Z}](\mathrm{b}), \mathrm{HSA}-[\mathrm{RhCp} *(\mathrm{dhp}) \mathrm{Z}]$ and HSA $-\left[\mathrm{RhCp} *\left(\mathrm{H}_{2} \mathrm{O}\right)_{3}\right]^{2+}$ systems (c) at pH 7.4 in PBS' buffer with the corresponding spectra of HSA and the RhCp* complexes. $\left\{c_{H S A}=0.5 \mathrm{mM}\right.$; $c_{R h C p^{*}}$ $=c_{L}=1 \mathrm{mM} ; \mathrm{T}=25{ }^{\circ} \mathrm{C}$; incubation time $=1$ or $24 \mathrm{~h} ; 10 \% \mathrm{D}_{2} \mathrm{O} ; \mathrm{Z}=\mathrm{H}_{2} \mathrm{O}$ or $\left.\mathrm{Cl}^{-}\right\}$.
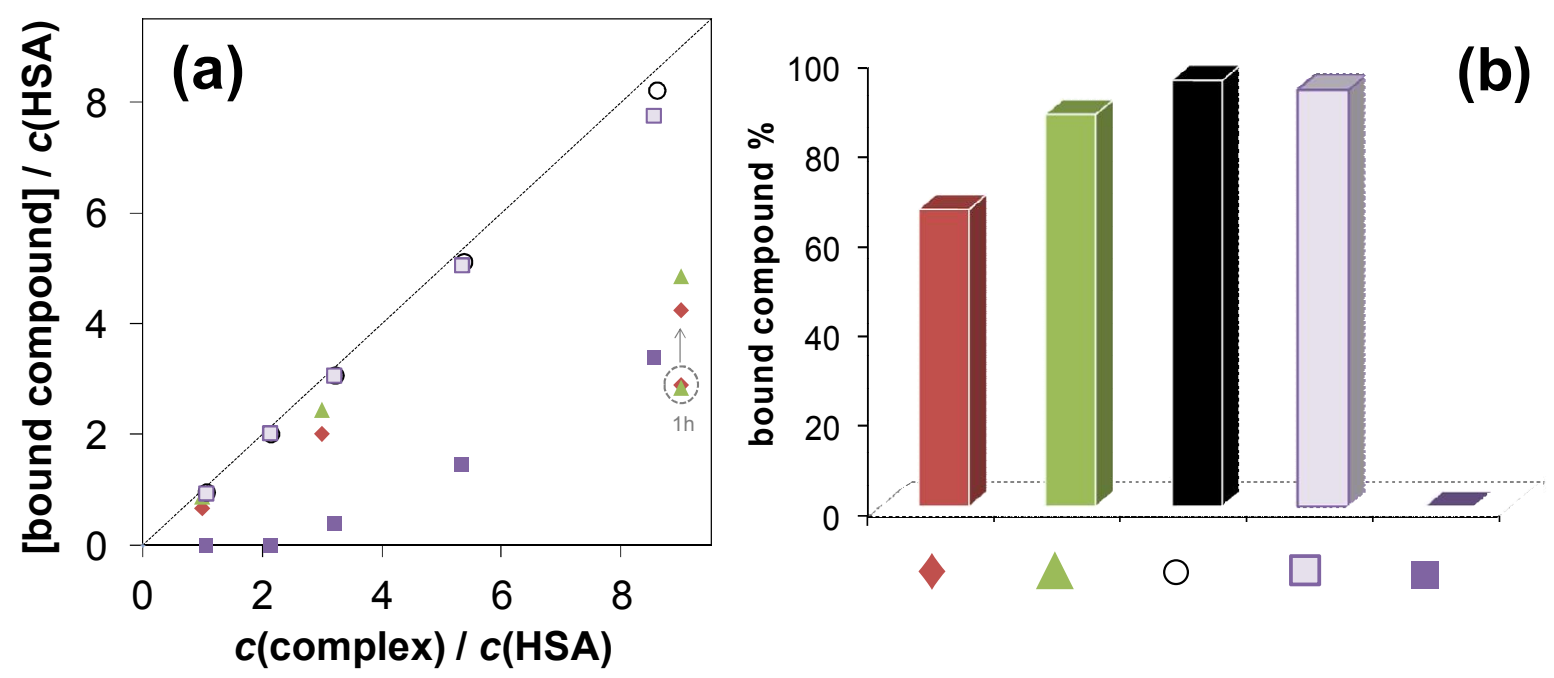

Fig. 8 Ratio of the bound compounds and HSA plotted against the ratio of the total concentrations of the complexes and HSA calculated from the UV-Vis spectra recorded for the LMM fractions of the ultrafiltered samples (a). Fractions (\%) of bound compounds at 1:1 complex-to-HSA ratio (b). Symbols: : bound $\left[\mathrm{RhCp}^{*}(\mathrm{en}) \mathrm{Z}\right]$ in the $\left[\mathrm{RhCp}^{*}(\mathrm{en}) \mathrm{Z}\right]-\mathrm{HSA}, \triangle$ : bound $\left[\mathrm{RhCp}^{*}(\mathrm{bpy}) \mathrm{Z}\right]$ in the $\left[\mathrm{RhCp} *\left(\right.\right.$ bpy)Z] $-\mathrm{HSA}$, ○: bound $\left[\mathrm{RhCp} *\left(\mathrm{H}_{2} \mathrm{O}\right)_{3}\right]^{2+}$ in the $\left[\mathrm{RhCp}^{*}\left(\mathrm{H}_{2} \mathrm{O}\right)_{3}\right]^{2+}-\mathrm{HSA}$, and $\square$ : bound $\left[\mathrm{RhCp} *\left(\mathrm{H}_{2} \mathrm{O}\right)_{3}\right]^{2+}$ and $\mathrm{m}$ : bound dhp in the $[\mathrm{RhCp} *(\mathrm{dhp}) \mathrm{Z}]$ - HSA systems. Values are the means of 
two parallel measurements (relative standard deviations: $\leq 4 \%) .\left\{c_{H S A}=50 \mu M ; p H=7.4\right.$ (PBS' buffer); $T=25{ }^{\circ} \mathrm{C}$; incubation time $=24 \mathrm{~h}$ (and $1 \mathrm{~h}$ in the case of [RhCp*(en)Z] $-H S A(9: 1)$ and [RhCp*(bpy)Z] - HSA (9:1) systems); $\mathrm{Z}=\mathrm{H}_{2} \mathrm{O}$ or $\left.\mathrm{Cl}^{-}\right\}$.

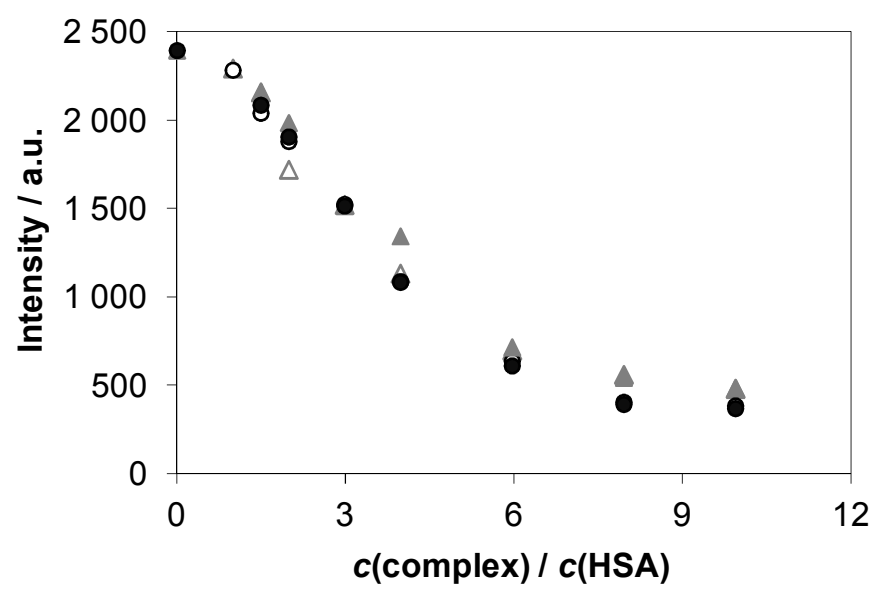

Fig. 9 Changes of fluorescence emission intensities at $340 \mathrm{~nm}$ plotted against the RhCp*-to-HSA ratios for the $\left[\mathrm{RhCp} *\left(\mathrm{H}_{2} \mathrm{O}\right)_{3}\right]^{2+}-\mathrm{HSA}(\circ, \bullet)$ and $\left[\mathrm{RhCp}^{*}(\mathrm{dhp}) \mathrm{Z}\right]-\mathrm{HSA}(\Delta, \Delta)$ systems measured after $1 \mathrm{~h}$ (empty symbols) and $24 \mathrm{~h}$ (filled symbols) incubation periods using $295 \mathrm{~nm}$ excitation wavelength. $\left\{c_{H S A}=1 \mu M ; p H=7.4\right.$ (PBS' buffer); $T=25{ }^{\circ} \mathrm{C} ; \mathrm{Z}=\mathrm{H}_{2} \mathrm{O}$ or $\left.\mathrm{Cl}^{-}\right\}$.

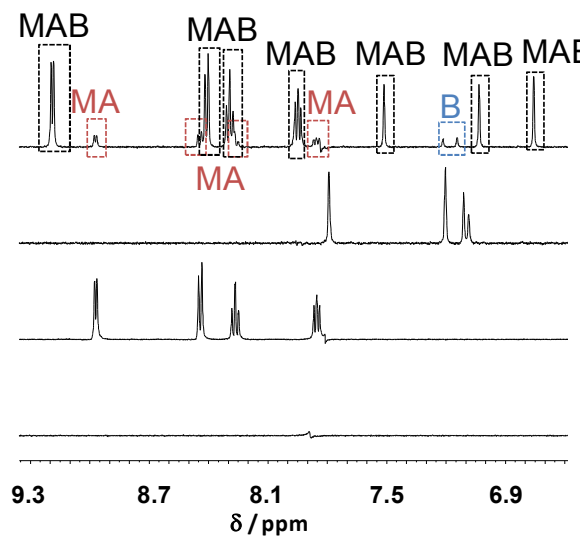

(a)

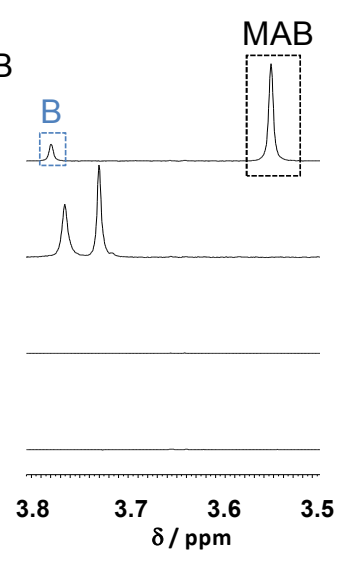

(b)

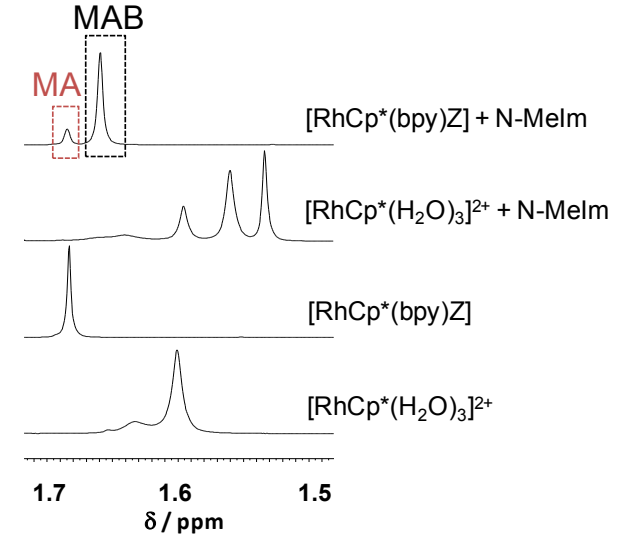

(c)

Fig. 10 Selected regions of the ${ }^{1} \mathrm{H}$ NMR spectra of $[\mathrm{RhCp} *(b p y) Z]-\mathrm{N}-\mathrm{MeIm}(1: 1),\left[\mathrm{RhCp}^{*}\left(\mathrm{H}_{2} \mathrm{O}\right)_{3}\right]^{2+}$ - N-MeIm (1:1) systems, [RhCp*(bpy)Z] and $\left[\mathrm{RhCp} *\left(\mathrm{H}_{2} \mathrm{O}\right)_{3}\right]^{2+}$ for comparison at $\mathrm{pH}$ 7.4. Regions of bpy and N-MeIm protons (a), methyl protons of N-MeIm (b), and $\mathrm{Cp}^{*}$ methyl protons (c). Symbols for the identified compounds: MAB: [RhCp*(bpy)(N-MeIm)], MA: [RhCp*(bpy)Z], B: N-MeIm. $\left\{c_{N-}\right.$ 
${ }_{\text {MeIm }}=c_{R h C p^{*}}=c_{b p y}=0.75 \mathrm{mM} ; \mathrm{T}=25{ }^{\circ} \mathrm{C} ; \mathrm{pH}=7.4$ (PBS' buffer); incubation time $=24 \mathrm{~h} ; 10 \% \mathrm{D}_{2} \mathrm{O}$;

$\mathrm{Z}=\mathrm{H}_{2} \mathrm{O}$ or $\left.\mathrm{Cl}^{-}\right\}$. 